\title{
Exploiting Conservation Lands: Can Hydrofracking Be Consistent with Conservation Easements?
}

\author{
Jessica Owley* and Collin Doane**
}

\section{INTRODUCTION}

When government agencies fail in their obligations to protect the environment, ${ }^{1}$ individuals and nonprofit organizations try to step in and fill what they see as the gaps in environmental protection. In the realm of land conservation, organizations (and wealthy individuals) have sought to increase numbers of acres protected through direct purchase of important lands. When full ownership of land is unobtainable or for other reasons undesirable, one of the most favored land-protection tools is the conservation easement. Conservation easements are already in widespread use across the United States, and the number of properties protected in this way is only likely to climb. Moreover, we are increasingly seeing the concept exported to other regions, and

\footnotetext{
* Professor of Law, SUNY Buffalo Law School and Profesora Visitante, Universidad Pontificia Comillas (ICADE). Thanks to Rob Jackson and Jim Salzman, who prompted us to commence this line of investigation. Leslie Ratley-Beach of the Land Trust Alliance, John Kramer of the Gates Mills Land Conservancy, and Kathleen McCormick of the Western New York Land Conservancy shared documents and conversation that helped guide our thoughts. A further thanks to Rob Jackson, Hannah Wiseman, and Gerry Korngold for reviewing this draft and sharing their expertise. ** Law Clerk, Lacy Katzen LLP; SUNY Buffalo Law School, Class of 2017.

1. The purpose of this Article is not to describe what we see as the contours of the government's obligation to protect the public trust of natural resources and environmental amenities. Moreover, we acknowledge that not everyone agrees that the government has such a responsibility. We firmly believe that it does and do not address it as a question of debate. Instead, we start from the understanding that actions undertaken by the government vary in their aggressiveness of environmental protection. Logically (and hopefully), when the government is less stringent in such protection or less willing to cover the costs of protective measures, nongovernmental entities will become more active. The tools available to individuals or nongovernmental groups are different and arguably less effective or extensive. In 2017, it appears we are on a trajectory of less environmental protection on the federal level with inconsistency in approaches of state and local governments. After the presidential election of Donald Trump at the end of 2016, environmental nongovernmental organizations saw a marked increase in donations and many expressed their intention to become even more active in the realm of environmental protection. Colby Itkowitz, 'It's Unprecedented in Our History': Trump's Election Inspired Millions in Nonprofit Donations, WASH. POST (Nov. 30, 2016), https://www.washingtonpost.com/news/inspired-life/wp/2016/11/30/its-unprecedented-in-ourhistory-after-trumps-election-millions-of-dollars-poured-into-nonprofits/?utm_term=.a62bdb22a76c.
} 
conservation easements (or similar arrangements) are becoming popular in many countries. ${ }^{2}$ The widespread use of the tool alongside the likelihood of its increasing importance leads us to examine how conservation easements function in conjunction with another growing trend: hydraulic fracturing (colloquially referred to as hydrofracking or fracking).

Conservation easements are generally conceived of as a way to prevent development, but their flexible nature enables them to promote almost any environmental goal with tailored restrictions as long as they meet general goals of land conservation as spelled out in state law. One of the hallmarks of the conservation easement is its perpetual nature alongside the idea that the property owner retains any rights not explicitly limited in the text of the conservation easement. Taken together, these two aspects of the tool can present a conundrum when an uncontemplated use of the land arises. Most conservation easements currently in place were not drafted with fracking in mind. That is to say, the drafters of the agreements did not contemplate that fracking might occur on, beneath, or next to the property and, therefore, the agreements do not address the issue. Only recently have landowners, conservation easement holders, energy companies, and courts begun to investigate the possibilities.

This Article examines the legality of fracking on land currently encumbered with conservation easements. The question cannot be answered simply, and we provide a roadmap for parties interested in

2. They are already well-established in Canada. Kimberly Good \& Sue Michalsky, SuMMARY OF CANADIAN EXPERIENCE WITH CONSERVATION EASEMENTS AND THEIR POTENTIAL APPLICATION TO AgRI-ENVIRONMENTAL POLICY, 12-13 (2008), http://publications.gc.ca/collections/ collection_2011/agr/A125-17-2011-eng.pdf. Australia and New Zealand have developed similar structures. Vanessa M. Adams \& Katie Moon, Security and Equity of Conservation Covenants: Contradictions of Private Protected Area Policies in Australia, 30 LAND USE POL'Y 114, 114-15 (2013); Caroline Saunders, Conservation Covenants in New Zealand, 13 LAND USE POL'Y 325, 325 (1996). Scotland has had a law in place for several years, and there is pending legislation for England and Wales. Colin T. Reid, The Privatisation of Biodiversity? Possible New Approaches to Nature Conservation Law in the UK, 23 J. ENVTL. L. 203, 212-14 (2011) (describing the development of conservation easements in Scotland); Conservation Covenants, LAW Comm'N, http://www.lawcom.gov.uk/project/conservation-covenants/ (last visited Oct. 2, 2017) (describing "recommendations for the introduction of a new statutory scheme of conservation covenants in England and Wales"). We also see examples popping up elsewhere. See, e.g., R. Watson, K. H. Fitzgerald \& N. Gitahi, Expanding Options for Habitat Conservation Outside Protected Areas in Kenya: The Use of Environmental Easements, AFricAn WiLdLIFE Found. 9-13 (Mar. 2010), https://www.awf.org/sites/default/files/media/Resources/Books\%20and\%20Papers/AWF_Env_Ease ment_Technical_Paper_2_March_2010.pdf (describing environmental easements in Kenya); M. Root-Bernstein et al., Conservation Easements and Mining: The Case of Chile, 1 EARTH'S FUTURE 33, 34-35 (2013) (describing environmental easements in Chile); Angel Salazar et al., Geomorphological Heritage and Conservation in Spain, in LANDSCAPES AND LANDFORMS OF SPAIN 307, 316 (F. Guitierrez \& M. Gutierrez eds., 2014) (describing a related program of land stewardship in Spain). 
assessing the potential of engaging in fracking-related activities on a parcel-by-parcel basis. The inquiry is a complicated one involving an assessment of the conservation easement involved, the various laws associated with it, and the environmental conditions of the land. Most conservation easement proponents appear to view fracking as inconsistent with conservation values and an inappropriate use of land protected by a conservation easement (almost regardless of the exact stated purpose of the conservation easement). ${ }^{3}$ To that end, increasingly land trusts are including language within conservation easements that explicitly address (and prohibit) fracking. ${ }^{4}$ Where they have done so, fracking cannot proceed on that property. ${ }^{5}$

Confusion arises, however, where the drafters of a conservation easement did not address possibilities of fracking, mining, or subsurface disturbance in the conservation easement agreement. Where land

3. See, e.g., Charles Belson, Land Conservation and Fracking Don't Mix: Letter to the Editor, CleVland.com,

http://www.cleveland.com/letters/index.ssf/2016/10/land_conservation_and_fracking.html (Oct. 7, 2016, 3:17 PM); Conservation, Not Fracking, THE VIRGINIAN-PILOT (Jan. 27, 2014), https://pilotonline.com/opinion/editorial/conservation-not-fracking/article_671f3566-2ae5-526bb82a-7e559d918c8b.html; Tim Eberly, Agency Policy Could Allow Fracking on Protected Land, THE VIRGINIAN-PILOT (Oct. 24, 2013), http://pilotonline.com/news/local/environment/agency-policycould-allow-fracking-on-protected-land/article_e4b69dd7-8f17-531e-a2b2-b3e7ad462e18.html;

Jaime McGeathy, Petition: Stop Fracking in Vulnerable Watersheds, FORCECHANGE.COM (Sept. 22, 2015), https://forcechange.com/103003/stop-fracking-in-vulnerable-watersheds/ [https://web.archive.org/web/20150922234534/https://forcechange.com/103003/stop-fracking-in-

vulnerable-watersheds/] (petition to the chair of the Virginia Outdoors Foundation to ban fracking on conservation easement properties that had gathered 261 signatures as of Sept. 22, 2015); Bri West, Fracking and Conservation Easements?, The Piedmont Envtl. Council (Oct. 21, 2013), https://www.pecva.org/land-conservation/conserving-your-land/945-fracking-and-conservationeasements. See also Gerald Korngold, Conservation Easements and the Development of New Energies: Fracking, Wind Turbines, and Solar Collection, 3 LSU J. OF ENERGY L. \& RES. 101, 102 (2014) [hereinafter Korngold, Conservation Easements] ("Environmentalism generally values land in its natural state and seeks to preserve it from development."). But see Lorie Woodward Cantu, Oil and Gas/Conservation Easements: Conservation Easements and Oil and Gas Development Are Not Mutually Exclusive, TEXAS WILDLIFE MAG., Oct. 2013, at 26-27, https://www.landcan.org/ pdfs/TWA-CEs\%20and\%20Oil\%20and\%20Gas-Oct-2013.pdf.

4. See, e.g., Gates Mills Land Conservancy's Declaration of Covenants, Conditions and Restrictions offered to Residents of Gates Mills Village (Mar. 13, 2017) (on file with author) (providing example of land trusts adding language into agreements clearly prohibiting fracking and other subsurface uses). More information of the Gates Mills Land Conservancy can be found on their website. GATES MiLlS LAND CONSERVANCY, http://www.gatesmillslandconservancy.org/ (last visited Oct. 2, 2017). See also The Dr. Lucinda Hart-Gonzalez Conservation Easement (Nov. 14 , 2012), https://angerandcourage.wordpress.com/2012/11/14/the-dr-lucinda-hart-gonzalez-conservatio n-easement/ (providing text of a conservation easement encumbering an organic farm in Pennsylvania banning fracking).

5. The interplay between conservation easements and unitization or forced pooling statutes is not yet clear, and it is not known whether encumbering land with conservation easements will subordinate rights under horizontal pooling scheme. This inquiry is the subject of a different research project with which the authors are involved. 
encumbered by a conservation easement is threatened by fracking, one must engage in a case-by-case inquiry to assess whether fracking can proceed on such lands. This case-by-case inquiry necessarily involves an investigation of the conservation easement agreement, conditions of the land, and statutes governing the conservation easement. These statutes may include state conservation easement enabling acts, the Internal Revenue Code, as well as any statutes that funded the conservation easement (for example the laws governing the U.S. Department of Agriculture's Forest Legacy Program). It may also include an investigation into laws regarding charitable organizations or where conservation easements are exacted, the land-use planning and permitting laws that underlie that exaction.

An example may help illuminate this. Let's say that thirty years ago, a land trust and landowner entered into a conservation easement in Pennsylvania with the stated goal of protecting the natural landscape and scenic views. A federal program funded the purchase of half the conservation easement. The then-landowner donated the remaining value and received significant tax benefits. Two changes of ownership later, the current landowner has learned that she can make a lot of money by leasing her subsurface rights to a fracking company. ${ }^{6}$ However, she knows that a conservation easement encumbers her land and is uncertain whether the fracking will be permitted. The conservation easement does not mention fracking or similar technology. There is, in fact, no explicit reference to the subsurface. To determine whether the landowner will be able to lease her property to a fracking company, we would have to examine the language of the conservation easement deed. Alongside this individual agreement, however, we would also want to review Pennsylvania's conservation easement act. Because part of the conservation easement was donated in exchange for a tax deduction, we would also need to consider the Internal Revenue Code rules for deductible conservation easements. We might also be interested in the federal program that financed the conservation easement, or perhaps in the charitable organization laws governing the land trust that holds the conservation easement. If we view the conservation easement as a charitable trust, we may also need to incorporate trust laws to answer this question. Because neither the state

6. Our example here, which may sound convoluted, is in fact a rather simple one. In many cases the owner of the surface and subsurface may be two different entities. A complicated question that we do not directly address is whether the owner of a subsurface estate could frack against the wishes of a surface owner where the surface is encumbered by a conservation easement. State property law rules about split estates protect the rights of subsurface owners to exploit the land. See Rachel Heron, Justin S. DuClos, \& Shaun A. Goho, The Interpretation of Surface Easements in Severance Deeds as a Limit on Hydraulic Fracturing Practices, 19 BuFF. ENVTL. L.J. 73, 76 (2012). We believe that where a subsurface owner has not agreed to a conservation easement, she cannot be bound by it. 
statutes nor the agreement itself contemplated fracking on land encumbered by conservation easements (suggesting neither default permission nor prohibition), the answer is not at all clear and will require an easement-by-easement investigation. This Article provides guidance for how one might conduct such an investigation and highlights sections of agreements and statutes that are most likely to cause a conflict. It is easy to see why we then end the Article by suggesting inclusion of a direct statement regarding fracking in state laws and in conservation easement agreements but also note that fracking is only one example where such confusion may arise and some default rules or canons of construction would be helpful in the context of conservation easements overall.

This Article begins in Part II by briefly explaining the mechanics of hydrofracking to demonstrate why it raises unique issues and differs from other types of energy exploitation. Part III then describes how conservation easements operate and Part IV brings these two elements together to answer our query: whether one can engage in hydrofracking on land currently encumbered by conservation easements. We quickly learn that there is no one answer to this question and instead a case-by-case inquiry is needed. ${ }^{7}$ We construct such a path and demonstrate how one might go about answering that question in various scenarios. We then, in Part V, offer guidance of what states, funders, conservation easement holders, and landowners might do to simplify the analysis. Thus, we are both (1) examining land encumbered with conservation easements today and investigating what the implications of fracking might be on those conservation easements (or vice versa) as well as (2) discussing how one might consider fracking on land yet-to-be-encumbered with conservation easements. To that end, we conclude with suggested language for future conservation easement agreements and, for some cases, proposed statutory or regulatory changes. In many ways, the conversation on fracking mirrors conversations we would have with other uncontemplated land uses and technologies. Lessons we learn in the fracking case can then help inform how conservation easements respond to unforeseen conditions.

\section{HYDROFRACKING 101}

Hyrdrofracking (or fracking) - short for hydraulic fracturing - is actually a stimulation technique used in the completion stage of oil and

7. And here we agree with Gerry Korngold who explained, "Determining [the environmental implications of fracking on conservation lands] would require a factual examination of the nature of any given operation, the particular parcel, and the effects on the land and surroundings." Korngold, Conservation Easements, supra note 3, at 116-17. 
gas production, ${ }^{8}$ but it has become shorthand for the larger process of horizontal drilling combined with the fracturing of subsurface rock formations using large volumes of water. ${ }^{9}$ This combination of horizontal drilling and hydraulic fracturing is used in many areas of the United States to recover oil and natural gas from tight shale and other similar formations. ${ }^{10}$ We use the term "hydrofracking" or "fracking" to cover the larger process of horizontal drilling and stimulation by hydraulic fracture. "Hydraulic fracturing" as used in this Article means the stimulation technique itself.

Oil and gas production entails numerous stages, including identifying and mapping target geological formations; constructing supporting infrastructure, such as well pads and roads; drilling and casing a well; well completion; production; reworking a well; and finally, reclamation of the well site. ${ }^{11}$ Much of the concern regarding hydrofracking stems from the drilling, completion, and production phases due to the amount of land disturbance, water usage, and emissions that occur during these stages.

The stimulation technique used in the hydrofracking process is not a new innovation. Fracturing an underground geological formation to improve production has been around since at least $1889,{ }^{12}$ and the technique of using pressurized water to drill for oil has been around for nearly seventy years. ${ }^{13}$ But the most common type of hydrofracking now used-slickwater fracturing, which uses large volumes of water-is a new technique. ${ }^{14}$ The rapid increase in the use of hydrofracking across the

8. U.S. Envtl. Prot. Agency, EPA/600/R-15/047a, Assessment of the Potential IMPACTS OF HYdRAUlic FRACTURING FOR OIL AND GAS ON DRINKING WATER RESOURCES (EXTERNAL REVIEW DRAFT) ES-1 (2015) [hereinafter EPA REPORT], http://ofmpub.epa.gov/ eims/eimscomm.getfile?p_download_id=523539.

9. See Alex Prud'homme, Hydrofracking: What EVEryone NeEdS to Know 24 (2014).

10. N.Y. St. Dep'T OF Envtl. Conservation, Final Supplemental Generic EnVironmental ImPact Statement on the Oil, Gas and SOlution Mining Regulatory Program 5-20 (2015) [hereinafter N.Y. ENVIRONMENTAL IMPACT STATEMENT], http://www.dec.ny.gov/docs/materials_minerals_pdf/fsgeis2015.pdf.

11. Beth E. Kinne, The Technology of Oil and Shale Gas Development, in BEYOND THE Fracking Wars: A Guide for Lawyers, Public OfFicials, Planners, and Citizens 3, 3-14 (Erica Levine Powers \& Beth E. Kinne eds., 2013).

12. TERENCE DAINTITH, Finders KeEPERS? HOW THE LAW OF CAPTURE SHAPED THE WORLD OIL INDUSTRY 27 (2010).

13. Inessa Abayev, Note, Hydraulic Fracturing Wastewater: Making the Case for Treating the Environmentally Condemned, 24 FORDHAM ENVTL. L. REV. 275, 294 (2013).

14. See N.Y. EnVironmental Impact Statement, supra note 10, at 5-34; TANya J. Gallegos \& Brian A. VARELA, U.S. GeOlOGiCAl SuRVEY, SCIENTIFIC INVESTIGATIONS REPORT 2014-5131, TRENDS IN HYdRAULIC FraCtURING Distributions AND TREATMENT Fluids, AdDitives, Proppants, AND Water Volumes APPLIED to Wells Drilled IN THE UNITED STATES FROM 1947 THROUGH 2010 - DATA ANALYSIS AND COMPARISON TO THE LITERATURE 9-10 (2015), https://pubs.usgs.gov/sir/2014/5131/pdf/sir2014-5131.pdf\#. 
United States that occurred in the early-to-mid $2000 \mathrm{~s}^{15}$ followed the advent of relatively newer innovations, such as horizontal drilling and the use of multi-well pads. ${ }^{16}$

Oil and gas wells are initially drilled vertically, but finished well orientations can be vertical, slanted, or horizontal. ${ }^{17}$ To accomplish horizontally oriented wells, well operators commonly drill vertically 5,000 to 13,500 feet deep, and then drill horizontally to a distance of 2,000 to 5,000 feet. $^{18}$ The logic behind drilling horizontally is that well operators can reach, and thus exploit, larger areas of the "thin and laterally extensive oil- and gas-bearing shales." 19 This technology developed and matured over decades, with some of the earliest horizontal wells drilled in the mid1980 s. $^{20}$

The use of multi-well pads and cluster drilling began in $2007 .^{21} \mathrm{~A}$ well pad is simply an area of land, typically between two and five acres and cleared of vegetation, in which a well is drilled. ${ }^{22}$ Therefore, as the name suggests, a multi-well pad is a pad with more than one well on it. Use of multi-well pads cuts costs. ${ }^{23}$ By drilling multiple wells from a single well pad, the drilling rig only needs to be moved short distances. ${ }^{24}$ Less movement means accelerated drilling times, fewer new roads, and less equipment. ${ }^{25}$ The combination of horizontal drilling and multi-well pads allows companies to produce oil and gas from unconventional sources, like shale formations, economically.

Hydraulic fracturing is performed in the completion stage, when preparing the well for production. ${ }^{26}$ During the hydraulic fracturing process, fluid is injected under high pressure down the wellbore and into

\footnotetext{
15. EPA REPORT, supra note 8, at ES-1.

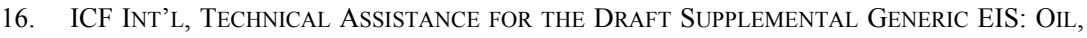
GaS AND SOlution Mining Regulatory Program 3-4 (2009).

17. EPA REPORT, supra note 8, at 2-10.

18. Id. at $2-2$

19. Id. at $2-10$.

20. Id. at 2-2.

21. N.Y. ENVIRONMENTAL IMPACt STATEMENT, supra note 10, at 5-1.

22. Kinne, supra note 11, at 6-7.

23. FRANK R. SPELLMAN, ENVIRONMENTAL IMPACTS OF HYDRAULIC FRACTURING 100 (2013).

24. Michael D. Holloway \& Oliver RudD, Fracking: The Operations and ENVIRONMENTAL CONSEQUENCES OF HYDRAULIC 65-66 (2013).

25. Id. at 66 .

26. U.S. ENVtl. Prot. Agency, EPA/601/R-14/002, Review OF Well Operator Files FOR Hydraulically Fractured OIL and Gas Production Wells: Well Design and CONSTRUCTION 7 (2015), https://www.epa.gov/sites/production/files/2015-05/documents/ wfr_1_final_5-8-15_508_km_5-13-15_sb.pdf.
} 
the subsurface rock formation. ${ }^{27}$ This fluid is typically comprised of water, chemical additives, and proppant ${ }^{28}$ (proppants are small grains of sand or ceramic beads). ${ }^{29}$ The high-pressure fluid induces fractures in the subsurface rock formation and carries and deposits the proppant into these fractures. ${ }^{30}$ Once deposited, the proppant holds (or props) the fractures open against the enormous subsurface pressure working to close the fractures. ${ }^{31}$ After the fluid returns to the surface, oil and gas begin to flow from the formation, into the wellbore, and then to the surface. ${ }^{32}$

Drilling and hydraulically fracturing a single horizontal well can take between two and twenty million gallons of water. ${ }^{33}$ A typical multi-well pad has between eight and sixteen wells per pad, which means many more millions of gallons of water are used per multi-well pad. ${ }^{34}$ Shipping all of this water and other supplies to a well pad requires between 20,800 and 41,600 (one-way) truck trips. ${ }^{35}$ These figures do not include additional truck trips associated with re-working a well. ${ }^{36}$

After a well is hydraulically fractured, it not only produces hydrocarbons, but it produces water as well. ${ }^{37}$ There are two types of water produced by the well-_flowback" and "produced water." ${ }^{38}$ Flowback is the water that initially returns from the formation after hydraulic fracturing, while produced water is the water produced later in time and usually returns while the well is simultaneously producing hydrocarbons. ${ }^{39}$ Flowback water resembles the hydraulic fracturing fluid, and produced water is more characteristic of the subsurface formation. ${ }^{40}$ Produced water can contain high concentrations of salt and even naturally occurring radioactive materials. ${ }^{41}$

27. EPA REPORT, supra note 8, at ES-1.

28. Id. at ES-10.

29. Kinne, supra note 11 , at 10.

30. EPA REPORT, supra note 8, at ES-1.

31. Id.

32. Id.

33. Robert B. Jackson, et al., The Environmental Costs and Benefits of Fracking, 39 ANNU. REV. ENVTL. RESOURCE 327, 329 (2014).

34. Kinne, supra note 11 , at 7.

35. See id. Drilling and fracturing a single well requires approximately 2,600 one-way truck trips. $I d$. Multiplying this number of truck trips by the lower and upper range of wells per pad results in a range of approximately 20,800 to 41,600 truck trips per well pad.

36. Id.

37. See Daniel Yergin, The Quest: Energy, Security, and the Remaking of the MODERN WORLD 330 (2011).

38. Id. at $330-31$.

39. See id.

40. See EPA REPORT, supra note 8, at ES-17.

41. Id. 
Once a well is producing hydrocarbons, it is connected first to a production line, which then connects to a gas or oil gathering line, and finally to a transmission pipeline. ${ }^{42}$ Other required infrastructure associated with oil and gas production includes treatment and storage technologies at the well site, such as oil-water separators and tanks, processing plants, and compressor stations. ${ }^{43}$ It is important to recognize that hydrofracking operations (indeed, all oil and gas production) necessitate an entire "midstream" industry, which includes the pipelines, processing plants, and compressor stations mentioned above, because these operations can also conflict with land conservation. The overall structure of hydrofracking operations demonstrates the potential for these operations to result in environmental impacts. In the next section, we highlight the main environmental impacts of hydrofracking.

\section{A. Environmental Impacts of Fracking}

The large amounts of water involved with hydrofracking raise three major water-related environmental concerns with the process: the water contamination (underground or at the surface), water depletion, and wastewater disposal. ${ }^{44}$

The risk that natural gas or wastewater will migrate underground and contaminate groundwater is no doubt a top concern among people who live near a hydrofracking operation. A high-profile case of groundwater contamination related to hydrofracking occurred in the township of Dimock, Pennsylvania, between 2006 and 2009 (the setting of the documentary GasLand). ${ }^{45}$ In the late 2000s, Dimock became the site of some of Pennsylvania's most productive gas wells. ${ }^{46}$ But after some time, residents of the Township began to notice that their water was an orange or brown color and that it smelled like sulfur. ${ }^{47}$ Water testing revealed "dangerous levels of methane, iron, and aluminum." 48 There were reports of pets and farm animals losing their hair, presumably from drinking the

\footnotetext{
42. Kinne, supra note 11 , at 12.

43. Id.

44. PRUD'HOMME, supra note 9, at 73.

45. Id. at 80-81. The film GasLand stirred much controversy when representatives from the oil and gas industry called into question some of the film's conclusions. See, e.g., Bryan Walsh, A Documentary on Natural Gas Drilling Ignites an Oscar Controversy, Time (Feb. 26, 2011), http://science.time.com/2011/02/26/a-documentary-on-natural-gas-drilling-ignites-an-oscarcontroversy/.

46. PRUD'HOMME, supra note 9, at 80 .

47. $I d$.

48. Id.
} 
tainted water. ${ }^{49}$ There have been other reported incidents of tainted groundwater due to hydrofracking as well. For example, a study conducted in Colorado concluded that methane reached "by drillers had migrated to dozens of water wells."

Another common concern regarding hydrofracking is water depletion. Although the amount of water used for a hydrofracking operation is typically a small percentage of the total water resource in a given basin, ${ }^{51}$ water is a local issue and impacts drilling communities severely. ${ }^{52}$ Hydrofracking requires the withdrawal of large quantities of water over a short period, and during periods of low flow, the large withdrawals can adversely affect aquatic life and municipal water supplies. ${ }^{53}$ The threat of water depletion is exacerbated by growing populations and droughts. ${ }^{54} \mathrm{In}$ Texas, the water used for hydrofracking "more than doubled between 2008 and 2011." 55

Disposal of hydrofracking wastewater is also a serious environmental concern. Again, Texas provides another unfortunate example of the deleterious effects of hydrofracking. In Texas, injection wells used to dispose of hydrofracking wastewater have become increasingly common. ${ }^{56}$ In 2005, wastewater from a disposal well in Texas contaminated the Pecos River Cenozoic Alluvium aquifer. ${ }^{57}$ The aquifer supplies drinking water to the City of Midland, Texas, and although there have been no reports of loss of drinking water, the contamination required much remediation. ${ }^{58}$ Injection wells have also been linked to induced seismicity. ${ }^{59}$ More recently, a study has shown a direct link between fracking and earthquakes. ${ }^{60}$

Other negative impacts of hydrofracking include, noise, odor, and poor air quality, all of which can harm the land and the people and animals

49. Id. at $80-81$.

50. Id. at 83 .

51. SPELlman, supra note 23, at 122.

52. See PRUD'HOMME, supra note 9, at 74.

53. SPELLMAN, supra note 23, at 122.

54. PRUD'HOMME, supra note 9, at 74-75.

55. Id. at 74 .

56. Id. at $88-89$.

57. Id. at 89 .

58. Hannah J. Wiseman, Risk and Response in Fracturing Policy, 84 U. Colo. L. Rev. 729, 791 (2013); Terrence Henry \& Kate Galbraith, As Fracking Proliferates, So Do Wastewater Wells, N.Y. TIMES (Mar. 28, 2013), http://www.nytimes.com/2013/03/29/us/wastewater-disposal-wellsproliferate-along-with-fracking.html?mcubz=1.

59. N.Y. ENVIRONMENTAL IMPACt STATEMENT, supra note 10, at ES-23-ES-24.

60. Id.; Xuewei Bao \& David W. Eaton, Fault Activation by Hydraulic Fracturing in Western Canada, 354 SCIENCE 1406, 1406 (2016). 
that live there. ${ }^{61}$ The location of well sites usually requires the construction of access roads. ${ }^{62}$ Roads and other infrastructure related to hydrofracking, such as well pads, pipelines, and compressor stations can cause habitat fragmentation, which threatens biological diversity. ${ }^{63}$ This infrastructure can also impair the aesthetics of a given area. ${ }^{64}$ Despite hydrofracking's harmful environmental impacts, it does produce some benefits, the most significant of which we have outlined below.

\section{B. Benefits of Hydrofracking}

Some argue hydrofracking benefits society by shifting energy production away from coal. ${ }^{65}$ Hydrofracking has enabled the United States to produce large amounts of domestic natural gas. ${ }^{66}$ For example, according to the U.S. Energy Information Administration, natural gas withdrawn from shale gas wells in January 2007 equaled 169,026 million cubic feet (MMCF), and that number rose to $1,330,132 \mathrm{MMCF}$ (equal to 1.33 trillion cubic feet) in December of $2015 .^{67}$ To put it more clearly: natural gas produced from shale gas wells in the United States grew nearly eightfold in less than nine years. ${ }^{68}$ This domestic natural gas is a cheaper, cleaner-burning fuel than coal or oil, which have been the major sources of U.S. energy consumption. ${ }^{69}$ Natural gas is not cleaner than renewable alternatives, which would be the least environmentally harmful energy sources, but some view natural gas as a necessary transition fuel on the path from fossil fuels to renewable energy. ${ }^{70}$

Many proponents of fracking have also supported its development as

\footnotetext{
61. N.Y. ENVIRONMENTAL IMPACt STATEMENT, supra note 10, at ES-2, E-22.

62. EPA REPORT, supra note 8, at 2-9.

63. N.Y. ENVIRONMENTAL IMPACT STATEMENT, supra note 10, at 6-70-6-72.

64. Id. at 6-234.

65. See, e.g., Joel Kirkland, Natural Gas Could Serve as 'Bridge' Fuel to Low-Carbon Future, SCI. AM. (June 25, 2010), https://www.scientificamerican.com/article/natural-gas-could-serve-asbridge-fuel-to-low-carbon-future/.

66. EPA REPORT, supra note 8, at ES-1.

67. U.S. Natural Gas Gross Withdrawals from Shale Gas, U.S. ENERGY INFO. ADMIN. (May 31, 2017), https://www.eia.gov/dnav/ng/hist/ngm_epg0_fgs_nus_mmcfm.htm [https://web.archive.org/ web/20170609080358/https://www.eia.gov/dnav/ng/hist/ngm_epg0_fgs_nus_mmcfm.htm].

68. 1,330,132 MMCF divided by 169,026 MMCF equals approximately 7.87 .

69. Order Approving Electric and Gas Rate Plans in Accord with Joint Proposal at 65, State of N.Y. Public Service Comm'n, Case 15-E-0283, et al. (June 15, 2016).

70. See, e.g., L.M. Cathles, Assessing the Greenhouse Impact of Natural Gas, 13 GEOCHEMISTRY GEOPHYSICS GeOSYSTEMS, June 2012, at 1, https://www.energyindepth.org/wpcontent/uploads/2012/07/Cathles-Assessing-greenhouse-impact-natgas-June2012.pdf; Todd Myers, Let's Embrace Natural Gas as a Transition Fuel, WALl ST. J. Blog (May 6, 2015, 9:00 AM), http://blogs.wsj.com/experts/2015/05/06/lets-embrace-natural-gas-as-a-transition-fuel/.
} 
a job creator. When viewed in the aggregate, hydrofracking has spawned some job growth and other beneficial economic activity. ${ }^{71}$ For example, in the counties of North Dakota and Montana that lie atop the Bakken Shale, employment grew by almost $36 \%$ from 2007 to $2011 .^{72}$ Workers in these counties saw an average annual pay increase of $53 \%$ over the same time period. ${ }^{73}$ On a national level, it is estimated that shale development supported 600,000 jobs in $2010 .{ }^{74}$ However, over the past two years, as oil and gas prices have remained low, employment has contracted in these areas. $^{75}$

With this understanding of the basics of fracking under our belts, we turn to a primer on conservation easements to help understand the interaction between this type of land use and a popular land restriction tool.

\section{CONSERVATION EASEMENTS 101}

Conservation easements are a popular conservation tool. ${ }^{76}$ It is estimated that over forty million acres of land in the United States are subject to conservation easements. ${ }^{77}$ A conservation easement is a nonpossessory interest in real property that restricts the development and use of land so as to advance conservation goals. ${ }^{78}$ It is essentially an agreement between the real property owner and the conservation easement

71. Sorell E. Negro, Man Camps, Boomtowns, and the Boom-and-Bust Cycle: Learning from Rifle, Colorado, and Williams County, North Dakota, in BEYOND THE FRACKING WARS: A GUIDE FOR LAwyers, Public OfFicials, PlanNERs, AND Citizens 193, 193, 195 (Erica Levine Powers \& Beth E. Kinne eds., 2013).

72. Paul Ferree \& Peter W. Smith, U.S. Bureau of Labor Statistics, Employment and Wage Changes in Oil-Producing Counties in the Bakken Formation, 2007-2011, 2 BLS: BEYOND THE NuMBERS, no. 11, 2013, at 2, https://www.bls.gov/opub/btn/volume-2/pdf/employment-wagesbakken-shale-region.pdf.

73. Id.

74. PRUD'HOMME, supra note 9, at 55.

75. Devashree Saha \& Mark Muro, Rigged: Declining U.S. Oil and Gas Rigs Forecast Job Pain, BROOKINGS (Mar. 16, 2016), https://www.brookings.edu/blog/the-avenue/2016/03/16/riggeddeclining-u-s-oil-and-gas-rigs-forecast-job-pain/.

76. See Federico Cheever \& Jessica Owley, Enhancing Conservation Options: An Argument for Statutory Recognition of Options to Purchase Conservation Easements (OPCEs), 40 HARV. ENVTL. L. REV. 1, 37 (2016).

77. Id. at 3. There is no comprehensive database of conservation easements in the United States, although the National Conservation Easement Database is trying to serve that function. As of October 2016, it contained data about nearly 25 million acres of conservation easements, but also admits that its database is not complete. Completeness, NAT'L CONSERVATION EASEMENT DATABASE, https://www.conservationeasement.us/completeness/ (last visited Sept. 30, 2017).

78. Jessica Owley, Exacted Conservation Easements: Emerging Concerns with Enforcement, 26 Prob. \& Prop. 51, 51 (2012) [hereinafter Owley, Exacted Conservation]. 
holder that the real property owner will not develop or use the land in a certain way. ${ }^{79}$ A conservation easement holder must be a government entity or charitable organization as detailed in state conservation easement enabling acts. ${ }^{80}$ The holder of the right is the entity that has the ability to enforce the agreement. ${ }^{81}$ The nonprofits that work with this tool are called land trusts, and there are over 1,700 of them across the United States. ${ }^{82}$ All fifty states along with the Virgin Islands and Washington D.C. now have conversation easement enabling acts, with the most recent being Wyoming's statute in $2005 .{ }^{83}$

Conservation easements can be created through sale, donation, eminent domain, judicial settlement, and exaction. ${ }^{84}$ While initial conservation easements were donated, we increasingly see the use of conservation easements in programs at all levels of government. This includes increased use of public funding of conservation easements and also using conservation easements in public permitting and development processes. ${ }^{85}$ The general allure of conservation easements is that they can

79. Isla S. Fishburn et al., The Growth of Easements as a Conservation Tool, 4:3 PLoS ONE 1, 1 (2009). Conservation easements can theoretically contain affirmative obligations as well as an obligation to undertake a certain act or to allow the holder to undertake a certain act, but the essential element of a conservation easement is a restriction. See, e.g., UnIF. CONSERVATION EASEMENT ACT WITH 2007 AMENDMENTS § 1(1) (UNIF. LAW COMM'N 2007) (defining conservation easements to include affirmative obligations); Alexander R. Arpad, Comment, Private Transactions, Public Benefits, and Perpetual Control over the Use of Real Property: Interpreting Conservation Easements as Charitable Trusts, 37 REAL PROP. PROB. \& TR. J. 91 (2002) (explaining that the affirmative aspect of conservation easements is often ignored). We have never seen a conservation easement that is purely affirmative.

80. Federico Cheever, Public Good and Private Magic in the Law of Land Trusts and Conservation Easements: A Happy Present and a Troubled Future, 73 DENV. U. L. REv. 1077, 1084 (1996) [hereinafter Cheever, Public Good].

81. Adina M. Merenlender et al., Land Trusts and Conservation Easements: Who Is Conserving What for Whom?, 18 CONSERVATION BIOLOGY 65, 68 (2004).

82. Every five years, the Land Trust Alliance performs a census - collecting information about land trusts and their activities. The 2010 census stated that there are over 1,700 land trusts in the United States. Katie Chang, Land Tr. All., 2010 National Land Trust Census Report 5 (2011), http://www.atlanticcoastconservancy.org/Documents/2010-final-report.pdf. See also Why Conserve Land, LAND TR. ALL., https://www.landtrustalliance.org/why-conserve-land/how-itworks/protected-forever (last visited Oct. 2, 2017) (using the 1,700 number). Oddly enough, the 2015 Census did not include any estimate of the number of land trusts. See Katie Chang, Land Tr. All., 2015 NATIONAL LAND TRUST CENSUS REPORT (2016), http://s3.amazonaws.com/ landtrustalliance.org/2015NationalLandTrustCensusReport.pdf. Over 1,000 land trusts are members of the Land Trust Alliance. Id. at 21.

83. Robert H. Levin, Land Tr. All., A Guided Tour of The Conservation Easement ENABLING STATUTES 4-5 (2010), http://conservationtools.org/library_items/1410-A-Guided-Tourof-the-Conservation-Easement-Enabling-Statutes.

84. Jessica Owley, The Enforceability of Exacted Conservation Easements, 36 VT. L. REV. 261, 261-62, 261-62 nn.1-8 (2011) [hereinafter Owley, Enforceability].

85. See, e.g., Short v. U.S. Army Corps of Eng'rs, 613 F. Supp. 2d 103, $104-05$ (D.D.C. 2009) (involving a dispute that arose as a result of a real estate developer allowing a conservation easement 
be perpetual. In California, Florida, and Hawaii, conservation easements are required to be perpetual, and in many states perpetuity is the default duration. ${ }^{86}$ Only North Dakota limits conservation easements to ninetynine years. ${ }^{87}$

The law governing conservation easements can be complex, and there are many sources of law that can affect them. ${ }^{88}$ Two sources of law are important to note. First, conservation easements must always comply with state enabling statutes. ${ }^{89}$ Second, if real property owners want federal charitable tax deductions, donated conservation easements must also comply with the Internal Revenue Code and Treasury Regulations. ${ }^{90}$ Alongside the enabling acts and tax provisions, other issues arise in the context of property law, funding and entitlement programs, and law governing charitable organizations and trusts.

\section{A. State Enabling Statutes}

State property law determines whether conservation easements are enforceable while federal law determines whether conservation easements are deductible. ${ }^{91}$ All conservation easements must comply with state law while only deductible conservation easements must comply with federal law. Historically, property rights similar to conservation easements were

on his property to protect wetlands in exchange for a developing permit); Rocky Mountain Christian Church v. Bd. of Cty. Comm'rs, 481 F. Supp. 2d 1213, 1227-28 (D. Colo. 2007) (upholding a conservation easement exacted by a county board of commissioners); Lake Mary Villas, LLC v. Cty. of Douglas, No. A05-717, 2006 WL 163515, at*1 (Minn. Ct. App. Jan. 24, 2006); Nat'1 Ass'n of Home Builders of the U.S. v. N.J. Dep't of Envtl. Prot., 64 F. Supp. 2d 354, 356 (D.N.J. 1999) (upholding the Hudson River Waterfront Area Rule, which conditioned development permits on exacted conservation easements for a thirty-foot-wide walkway on waterfront property).

86. California, Hawaii, and Florida require conservation easements to be perpetual (CAL. CIV. CodE $§ 815.2$ (b) (West 2007); Fla. Stat. AnN. § 704.06(2) (West 2013); Haw. Rev. Stat. AnN. $\S$ 198-2(b) (West 2008)) as does the Internal Revenue Code, for those hoping to associate their conservation easement with a tax deduction (I.R.C. $\$ 170(\mathrm{~h})(2)(\mathrm{c})(2012)$ ). See also Gerald Korngold, Solving the Contentious Issues of Private Conservation Easements: Promoting Flexibility for the Future and Engaging the Public Land Use Process, 2007 UTAH L. REV. 1039, 1050-51 (2007) [hereinafter Korngold, Solving the Contentious Issues] (describing the perpetual aspect of conservation easements).

87. North Dakota limits conservation easements to ninety-nine years generally, and further limits waterfowl habitat easements to fifty years. N.D. CENT. CODE ANN. § 47-05-02.1 (West 2008 \& Supp. 2013); N.D. CENT. CODE § 20.1-02-18.2 (West 2008); LEVIN, supra note 83, at 4.

88. Federico Cheever \& Nancy A. McLaughlin, An Introduction to Conservation Easements in the United State: A Simple Concept and a Complicated Mosaic of Law, 1 J. L. Prop. \& SoC'Y 107, 114 (2015).

89. Id.

90. Id. at $114-15$.

91. See supra notes 88-90 and accompanying text. 
disfavored by state common law of property ${ }^{92}$ - the logic being that private agreements that restricted land use reduced the marketability of the land (and that would be a bad thing). ${ }^{93}$ States eventually passed conservation easement enabling statutes that overcame the common law obstacles. ${ }^{94}$ These enabling statutes furthered conservation goals while still allowing real property to remain productive and in private hands. These state enabling statues are the primary governing authority for all conservation easements.

While various state enabling acts differ slightly, they follow similar patterns of setting forth acceptable purposes and affirming that the arrangements are permissible under state law. The NCCUSL (National Conference of Commissioners on Uniform State Law) authored a Uniform Act in $1981 .^{95}$ The Uniform Conservation Easement Act (UCEA) served as the model for almost half the states. ${ }^{96}$ The purpose of the UCEA was to sweep away the impediments of common law that made enforcement of perpetual negative easements in gross uncertain; common law courts did not generally enforce perpetual restrictions on land uses except by an adjoining landowner. ${ }^{97}$ The prefatory notes to the UCEA indicate that the drafters did not believe that they were creating something new, but simply clarifying the enforceability of a mechanism that in many cases already existed. ${ }^{98}$ Many states were influenced by the UCEA, either adopting it outright or embracing some provisions. ${ }^{99}$

Because conservation easements are essentially negative easements in gross that run with the land, state property law disfavored them. ${ }^{100}$ When

92. See, e.g., Wetlands Am. Tr., Inc. v. White Cloud Nine Ventures, L.P., 782 S.E.2d 131, 145 (Va. 2016) (Roush, J., dissenting) (explaining that easements in gross were disfavored under the common law); United States v. Blackman, 613 S.E.2d 442, 446 (Va. 2005) (explaining lack of transferability of easements in gross because they were strongly disfavored); RESTATEMENT (THIRD) OF Prop.: SERVITUdES $§ 1.6 \mathrm{cmt}$. a (AM. LAW InST. 2000); Jessica E. Jay, When Perpetual Is Not Forever: The Challenge of Changing Conditions, Amendment, and Termination of Perpetual Conservation Easements, 36 HARV. ENVTL. L. REV. 1, 26 (2012) (describing the need to "sweep away" common law impediments to conservation easements).

93. Nancy A. McLaughlin, Perpetual Conservation Easements in the 21st Century: What Have We Learned and Where Should We Go from Here?, 2013 UTAH L. REV. 687, 696-97 (2013).

94. See Mary Ann King \& Sally K. Fairfax, Beyond Bucks and Acres: Land Acquisition and Water, 83 Tex. L. ReV. 1941, 1960 (2005).

95. UNIF. CONSERVATION EASEMENT ACT (UNIF. LAW COMM'N 1981).

96. Legislative Enactment Status Conservation Easement Act, UNIF. L. Comm'N, http://www.uniformlaws.org/LegislativeMap.aspx?title=Conservation\%20Easement\%20Act (last visited Oct. 2, 2017).

97. Nancy A. McLaughlin, Rethinking the Perpetual Nature of Conservation Easements, 29 HARV. ENVTL. L. REV. 421, 426 (2005).

98. See Unif. Conservation Easement Act Prefatory Note.

99. See LEVIN, supra note 83, at 8 .

100. UNIF. CONSERVATION EASEMENT ACT With 2007 AMENDMENTS $§ 4$ and cmts. (UNIF. LAW 
the state legislatures passed the enabling acts, they were very careful to circumscribe the types of restrictions that they would allow. ${ }^{101}$ Thus, state conservation easement statutes outline lists of acceptable purposes of conservation easements. States require that conservation easements be created for conservation purposes intended to benefit the public. Acceptable purposes for conservation easements under the UCEA "include retaining or protecting natural, scenic, or open-space values of real property, assuring its availability for agricultural, forest, recreational, or open-space use, protecting natural resources, maintaining or enhancing air or water quality, or preserving the historical, architectural, archaeological, or cultural aspects of real property." 102

The NCCUSL lists twenty-three states as having adopted the UCEA in some form. ${ }^{103}$ While not all of the states listed as adopting the UCEA adopted the UCEA's list of purposes verbatim, they generally have the same list of permissible purposes (and a few states have added slightly to it). ${ }^{104}$ Additionally, all state statutes limit permissible holders (enforcers)

\footnotetext{
COMM'N 2007)

101. Id.

102. Id. § 1(1).

103. Legislative Fact Sheet - Conservation Easement Act, UNIF. LAW COMM'N, http://www.uniformlaws.org/LegislativeFactSheet.aspx?title=Conservation $\% 20$ Easement $\% 20$ Act (last visited Sept. 30, 2017). Washington, D.C., and the Virgin Islands have also adopted the UCEA. Id.

104. Adopting the purposes sections directly (or with small changes that do not affect our analysis) are Alabama, Alaska, Arkansas, Delaware, Idaho, Indiana, Kansas, Kentucky, Maine, Minnesota, Mississippi, Nevada, Oregon, South Carolina, South Dakota, Texas, Virginia, Wisconsin, and Wyoming. ALA. CODE $§ 35-18-1(1)$ (2014) (also allowing for protection of paleontological resources and includes silvicultural uses as distinct from agriculture or forests); ALASKA STAT. ANN. $\S 34.17 .060$ (1) (West 2007 \& Supp. 2014); ARK. CODE ANN. § 15-20-402(1) (West 2011); DEL. CoDE ANN. tit. 7, § 6901(1) (West 2006) (adding protection of "fish and wildlife habitat, rare species and natural communities"); IDAHO CODE ANN. § 55-2101(1) (West 2006); IND. CODE ANN. § 32-23-5-2 (West 2013); Kan. Stat. AnN. § 58-3810(a) (West 2008); Ky. ReV. Stat. AnN. § 382.800(1) (West 2006); Me. Rev. Stat. AnN. tit. 33, § 476(1) (West 1999 \& Supp. 2013); MinN. Stat. AnN. § 84C.01(1) (West 2014); Miss. Code ANN. § 89-19-3(1) (West 1999); NeV. REV. STAT. § 111.410(1) (West 2013); OR. ReV. STAT. ANN. § 271.715(1) (West 2007); S.C. CODE ANN. § 27-8-20(1) (2007); S.D. Codified Laws § 1-19B-56(1) (2012); TEX. NAT. RES. CODE ANN. § 183.001(1) (West 2011); VA. CODE ANN. § 10.1-1009 (West $2011 \&$ Supp. 2014); Wis. STAT. ANN. § 700.40(1)(a) (West 2001 \& Supp. 2013) (adding protection of burial sites); Wyo. STAT. ANN. § 34-1-201(b)(i) (West 2007 \& Supp. 2014). While New Mexico is officially categorized as a UCEA state, its purposes section is different. Legislative Fact Sheet, supra note 103. New Mexico views conservation easements as "retaining or protecting natural or open space values of real property, assuring the availability of real property for agricultural, forest, recreational or open space use or protecting natural resources." N.M. StAT. ANN. § 47-12-2(B) (West 2003). Additionally, six non-UCEA states have adopted purposes sections that are substantially similar to the one in the UCEA: Georgia, Louisiana, Missouri, Nebraska, Oklahoma, and West Virginia. GA. CodE ANN. § 44-10-2(1)(West 2003); LA. STAT. ANN. § 9:1272(1) (2008); Mo. ReV. Stat. § 442.014.2(1) (West Supp. 2017); Neb. ReV. Stat. ANN. § 76-2,111(1) (West 2009) (adding any purpose as may qualify as a charitable contribution under the Internal Revenue Code); OKLA. STAT. ANN. tit. 60, § 49.2.1 (West 2010); W. VA. CODE ANN. § 20-12-3(a)
} 
of conservation easements to government entities or nonprofit organizations. ${ }^{105}$ Although the variations in purposes and holders among the states tend to be slight, you must carefully appraise the statute of the state you are operating in.

\section{B. Internal Revenue Service Requirements}

In many instances, conservation easements are donated so that the landowner can receive a tax benefit. ${ }^{106}$ Conservation easements that are donated for a charitable tax deduction must comply with federal tax statutes and regulations. ${ }^{107}$ The Internal Revenue Code does not allow tax deductions for partial interests, with the sole exception of conservation easements. ${ }^{108}$ Internal Revenue Code section 170(h) allows tax deductions for qualifying conservation easements in an amount equal to the value of the conservation easement. ${ }^{109}$ Many state tax incentive programs require compliance with the federal tax requirements as well. ${ }^{110}$

A conservation easement must satisfy four requirements to be eligible for a federal tax deduction. The conservation easement must be (1) granted in perpetuity; (2) to a government entity or publicly-supported charity; (3) exclusively for one or more of four conservation purposes; and (4) the conservation purpose must be protected in perpetuity. ${ }^{11}$ The four acceptable conservation purposes are (1) habitat protection; (2) preservation of open space; (3) historic preservation; and (4) preservation of land for outdoor recreation by the general public and education of the general public. ${ }^{112}$

\section{HYDROFRACKING ON LAND ENCUMBERED BY CONSERVATION EASEMENTS}

With an understanding of the basic environmental concerns that might arise with fracking, it is unsurprising that some conservationists may seek to limit the ability to frack on protected land. At the same time, however,

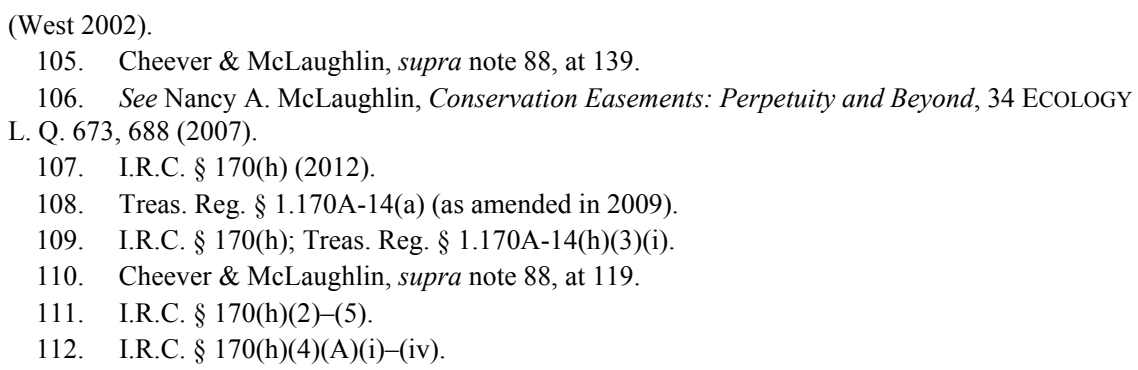


landowners may see opportunities with fracking. For example, fracking may enable a landowner to generate income while limiting intensive surface uses like real estate development. If a landowner can dedicate a small area to a well pad in exchange for protection of large surface areas providing environmental benefits, fracking may appear consistent with conservation goals. Indeed, if the well pads are on neighboring lands and the conservation lands are reached solely through horizontal drilling, the activity may appear even more attractive. ${ }^{113}$

We can envision scenarios where the parties involved in conservation transactions may wish to prohibit or permit fracking. A concern emerges where the parties did not contemplate fracking and do not have an agreement on whether it should be permitted on the land. Additionally, there may be cases where the parties involved in creating and enforcing the conservation easement (e.g., the landowner and land trust) find fracking an acceptable land use but members of the public object. In such cases, can conservation easement law provide citizens with a tool to prevent exploitation of the subsurface resources? These questions are not easy to answer and differ based on the text of the agreement itself as well as the state and federal laws operating in each situation. We examine these issues in turn.

This section is framed in terms of steps that one should take in assessing the ability to conduct fracking activities on lands encumbered by conservation easements. Thus, the following headings are numbered steps in the order that we advise tackling the issue. In matter of fact, the order of these steps matters little as long as one remembers to investigate all of these topics. We have put them in the order that we find to be the most logical. In particular, we think the question of whether fracking is permissible will most commonly be answered by a consideration of the first step alone. Complete prohibitions on fracking (where the answer will be "no, it is not allowed") are most likely to come from the deed of the conservation easement itself.

\section{A. Step One: Look at the Conservation Easement Deed}

We begin by examining the conservation easement itself. In this project, we are most interested in the implications for land already

113. Colin Jerolmack, Fighting Climate Change Is Hard When You Live on a Natural Gas Reserve, SLATE (May 20, 2016, 12:10 PM), http://www.slate.com/articles/health_and_science/ science/2016/05/one_town_s_reaction_to_fracking_explains_why_the_battle_against_climate.html (describing a landowner's decision to allow fracking below her land already encumbered with a conservation easement). 
encumbered by conservation easements. ${ }^{114}$ In the vast majority of cases, this means conservation easements that do not contain any terms regarding fracking. If we had language regarding fracking within the agreement itself, that language would control as long as it did not conflict with any state or federal laws. ${ }^{115}$ We take such conservation easements as being the easy case and, therefore, not meriting discussion here. This section delves into conservation easements written without contemplation of the potential for exploitation of oil or natural gas using hydrofracking techniques. ${ }^{116}$ In the following sections, we examine the state and federal laws that would still require compliance regardless of the text of the conservation easement.

Even where a conservation easement does not directly mention fracking, mining, or subsurface activity; other provisions within the agreement may prove an impediment to exploitation of subsurface resources. There is no required format for conservation easements in any state, nor are there required elements beyond the format necessary for recording any deed. Thus, we offer here some example provisions that could hamper fracking, but these are not an exhaustive list of such provisions. Such impediments are most likely to appear either in the list of purposes or in the individual land-use restrictions written into the agreement.

\section{Conservation Easement Purposes}

Conservation easements generally contain provisions listing the purposes for which the land is being protected. ${ }^{117}$ While they are required

114. Elsewhere, we have discussed the possibility of using conservation easements specifically to prevent fracking and that discussion focused on the creation of new agreements. See generally Robert B. Jackson et al., Mineral Estate Conservation Easements: A New Policy Instrument to Address Hydraulic Fracturing and Resource Extraction, 47 ENVTL. L. REP. 10112 (2017).

115. Or generally concepts of public policy. See, e.g., Nahrstedt v. Lakeside Vill. Condo. Ass'n, 878 P.2d 1275, 1286 (Cal. 1994) ("Equity will not enforce any restrictive covenant that violates public policy."). This could be a tricky point for fracking if at some point the common law evolves to recognize any restraint on mineral exploitation as against public policy.

116. As Korngold laments, "[i]n an ideal transactional world, [energy development] is a matter that the parties (or their lawyers) considered, negotiated, agreed upon, and reduced to clear, comprehensible language." Korngold, Conservation Easements, supra note 3, at 118.

117. Only some states specifically require that the agreements contain a section detailing the purpose of the conservation easement. IOWA CODE ANN. § 457A.4 (West 2013) ("A conservation easement shall clearly state its extent and purpose."). Maine also requires that a conservation easement "include a statement of the conservation purposes of the [conservation] easement, the conservation attributes associated with the real property and the benefit to the general public intended to be served by the restriction on uses of the real property subject to the conservation easement." ME. REV. STAT. ANN. tit. 33, § 477-A(1) (West Supp. 2013). Utah states that "[t]he instrument that creates a conservation easement shall identify and describe the land subject to the conservation easement by 
to set forth acceptable purposes under state and (where applicable) federal law, there is no set format or placement of these purposes within the document. While state enabling acts and the IRS code provide guidelines for acceptable purposes, most conservation easements contain several purposes-increasingly so. ${ }^{118}$ In efforts to encompass multiple potential future circumstances (or perhaps just due to sloppy drafting), the stated purposes may also be vague.

Where fracking would directly conflict with a conservation easement's identified purposes, it will not be allowed. Whether it does actually conflict, however, is open to interpretation and debate. If the conservation easement contains no direct references to fracking, it may be hard to argue that the overall purposes of the conservation easement conflict with fracking in any form. For example: does a scenic easement prevent fracking? While it might prevent the actual drilling from occurring on the land, arguably there is nothing to prevent horizontal drilling where it will not change the pretty view. Yet, strong evidence of subsidence in an area due to fracking may be an argument against allowing it in a particular case. This leads to a two-part inquiry that makes it a mixed investigation of law and fact. One would need not only investigate the details of the conservation easement agreement (law), but also the conditions of the land and the likely impacts from fracking (fact).

Most conservation easements state a goal of slowing development and protecting the natural state of the land. It is not clear that such goals would be impacted by enabling the development of subsurface oil and gas resources. With simply a legal inquiry into the text of the agreement, a court would be hard pressed to conclude that the agreement prohibited all forms of subsurface exploitation or fracking.

Some conservationists argue that hydrofracking is so inherently risky for the environment that it is never consistent with conservation. One court in Ohio was at least willing to take the presence of a conservation easement on a property as evidence of a commitment to environmental protection that is, at heart, inconsistent with hydrofracking subsurface

legal description, specify the purpose for which the [conservation] easement is created, and include a termination date or a statement that the [conservation] easement continue in perpetuity." UTAH CODE ANN. § 57-18-4(3) (West 2004 \& Supp. 2013). However, because conservation easements must satisfy the purpose requirements under state and sometimes federal law, all of the conservation easements we have reviewed state their purposes in some format.

118. See Jessica Owley \& Adena Rissman, Trends in Private Land Conservation: Increasing Complexity, Shifting Conservation Purposes and Allowable Private Land Uses, 51 LAND USE POL'Y 76, 77 (2016) (examining changes in conservation easements over time and finding, inter alia, an increase in the number of purposes identified in the average conservation easement). 
resources. In Beaverkettle Farms, Ltd. v. Chesapeake Appalachia, LLC, ${ }^{119}$ the landowners argued that their decision to encumber part of their land with a conservation easement indicated their genuine interest in protecting the land for conservation (as opposed to simply trying to get a better price on a subsurface lease). ${ }^{120}$

In Stockport Mountain Corp. v. Norcross Wildlife Foundation, Inc. (Stockport I), ${ }^{121}$ a case discussed in more detail below, the plaintiffs pursued fracking development on a parcel encumbered by a conservation easement. ${ }^{122}$ The conservation easement had a purposes section, where it set forth its goal as

the protection of plant life and wildlife biodiversity and the protection of wildlife habitats; and conserving and protecting the Property from soil erosion, water pollution, development, fragmentation, and other occurrences which might interfere with the Property's Conservation Values, or with the beauty and unique character of the Property as it exists in its current state. ${ }^{123}$

As is common, the conservation easement also contained an enumeration of "Conservation Values." " Although the case does not provide the list of conservation values, they are generally terms that describe the current environmental amenities or ecosystem services associated with the parcel. The conservation easement also contained specific land-use restrictions, presumably the terms that help achieve the purpose of the conservation easement. ${ }^{125}$ On a motion to dismiss, the court found the conservation easement text ambiguous. ${ }^{126}$ As the drafters had not addressed fracking in the conservation easement, the court was uncertain as to how to interpret the agreement and declined to dismiss at that stage. ${ }^{127}$ While it appeared that the conservation easement's general

\footnotetext{
119. No. 4:11CV02631, 2013 WL 4679950 (N.D. Ohio Aug. 30, 2013) landowners' denial. $I d$.

121. No. 3:11cv514, 2012 WL 719345 (M.D. Pa. Mar. 1, 2012).

122. Id. at *7.

123. Id.

124. Id.

125. Id.

126. Id. at *8.

127. Id. at $* 7-8$.
}

120. Id. at *7-8. This case did not investigate a conflict between fracking and a conservation easement but instead whether the landowners had reasonably withheld permission to develop subsurface rights. $I d$. at *1. The landowners argued that they were hesitant about allowing the lessor to frack the land because of their concerns about the environmental impact on a beloved creek. $I d$. at *7. The lessors argued that the landowners were just trying to cancel the current lease to negotiate a more lucrative one. $I d$. at *8. The presence of the conservation easement along with other testimony led the court to conclude that there was a genuine issue of fact regarding the reasonableness of the 
purpose was to prevent intense extractive activities like fracking, other sections of the agreement expressly approved of other activitiestimbering, quarrying, construction of four residences, etc.- that appear contrary to its purpose. ${ }^{128}$ The court did not delve into whether the general purposes or other provisions of the conservation easement prohibited fracking because it found the prohibition on commercial activity easily resolved the dispute. The land-use restrictions in Stockport are discussed in more detail below, but we see that the general purposes section and description of conservation values on their own were inadequate to prohibit fracking in all circumstances.

\section{Land-Use Prohibitions}

Potentially more helpful than reviewing the purposes section in a conservation easement, is close examination of the individual terms restricting land uses. Here, we see a great variety in style and severity. Some conservation easements prohibit nearly all land uses while others are more permissive, enabling development and active use of portions of the land. If a conservation easement prohibits all subsurface use of the land (and the person/entity holding the subsurface rights was party to the conservation easement), there is a strong case for prohibiting fracking of any type. There may also be less obvious provisions that limit the ability to frack.

A common provision contained in many conservation easements is a prohibition on commercial activity. At least one court has held that such a provision prohibits fracking: Stockport Mountain Corp. v. Norcross Wildlife Foundation, Inc. (Stockport II). ${ }^{129}$ In 2002, Stockport Mountain Corporation purchased a property in Pennsylvania that was subject to a conservation easement whose purposes are described above. ${ }^{130}$

In 2007, Stockport learned that there may be valuable gas deposits under the land, and it was approached by several oil and gas companies about leasing the mineral rights. ${ }^{131}$ The original parties to the conservation easement had not contemplated fracking when drafting the agreement, and it appears that Stockport may have been unaware of the possibility when it purchased the land. ${ }^{132}$ Stockport approached the land trust holding the conservation easement, Norcross Wildlife Federation, to obtain approval

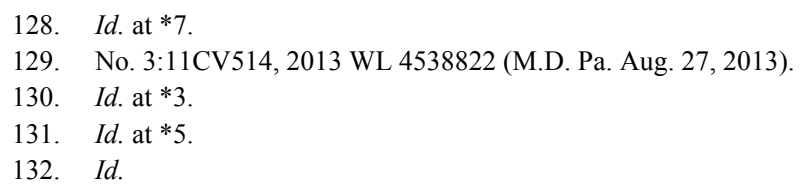


to lease the subsurface rights. ${ }^{133}$ The land trust denied the landowner's request to allow fracking on the property. ${ }^{134}$ Stockport filed suit arguing that because the conservation easement did not explicitly restrict fracking, Stockport retained the ability to lease its mineral rights for development. ${ }^{135}$

Generally, courts interpret conservation easements as only limiting landowners' rights where the agreement explicitly does so. Anything left unsaid therefore, is supposed to be in the landowners' realm. How explicit must a conservation easement be though? Generally, the law disfavors encumbrances on land, so when we read conservation easements, we read them as only restricting use of the land in the ways specifically detailed in the agreement. That is, the default assumption in property law is free use and alienability of land. Restraints on land uses hamper alienation (it is harder to sell something that has restrictions on it, and it is hard to remove restrictions if you have to go around and negotiate with everyone who has nonpossessory interests in your property), so the law construes them narrowly. Such a default presumption works in favor of landowner autonomy and instructs conservation easement holders to carefully construct agreements to ensure that they have obtained all the rights and interests they need to pursue their goals. Courts generally follow this interpretative approach but do not uniformly do so.

Norcross Wildlife Federation asserted that leasing mineral rights on the land would be a violation of the conservation easement for several reasons. ${ }^{136}$ First, as mentioned in the previous section, Norcross asserted that fracking was inconsistent with the general purpose of the conservation easement, which included protection of plant and wildlife with special concern for impacts from soil erosion and water pollution. ${ }^{137}$

The land trust also argued that several of the specific prohibitions within the conservation easement would be violated by allowing fracking. ${ }^{138}$ The conservation easement prohibits "[i]ndustrial or commercial uses of any kind," "commercial mining and/or quarrying of any kind," and "release of any . . c chemical substances on the Property."139 It also prohibits "[n]ew roads, except to provide low-impact temporary access to logging." 140 At the same time, the conservation easement

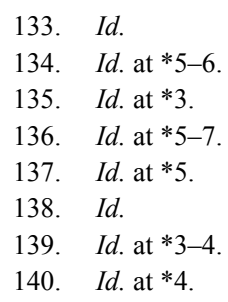


specifically allows some quarrying and timbering activities, as well as certain hunting and fishing activities. ${ }^{141}$

At first examination in addressing a motion to dismiss, the court found the conservation easement ambiguous on all fronts. On a later motion for summary judgment, however, the court held that the conservation easement was not ambiguous in its prohibition on fracking. ${ }^{142}$ In reaching this holding, the court looked not to the general purposes section but to the individual land-use restrictions enumerated in the agreement. ${ }^{143}$ Specifically, the court concluded that it did not need to look further than the section of the conservation easement that prohibited any commercial or industrial uses of any kind. ${ }^{144}$ The court concluded that drilling for natural gas is clearly a commercial and industrial use, and is therefore prohibited by the conservation easement. ${ }^{145}$ The "commercial activity" language that ultimately prevented Norcross from leasing its mineral rights was obviously less than optimal compared with an express prohibition on oil and gas extraction. But conservation easement holders can still face challenges even where a conservation easement expressly prohibits oil and gas extraction.

The facts of Ray v. Western Pennsylvania Conservancy ${ }^{146}$ illustrate how even seemingly clear, unequivocal language can come under attack. In Ray, the plaintiffs' predecessor in interest granted a conservation easement to Western Pennsylvania Conservancy. ${ }^{147}$ Within a month of the grant of the conservation easement, the land was conveyed to the Rays. ${ }^{148}$ Approximately three years after that conveyance, the Rays notified the Conservancy of their intention to explore for and extract natural gas from beneath the protected property via horizontal drilling from an adjacent

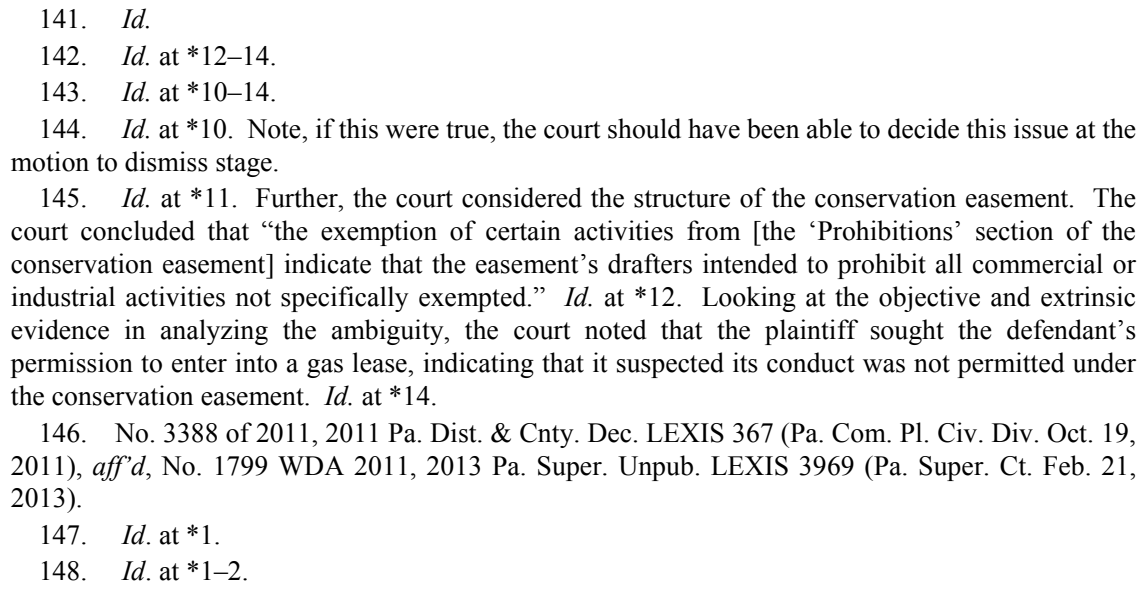

145. Id. at *11. Further, the court considered the structure of the conservation easement. The court concluded that "the exemption of certain activities from [the 'Prohibitions' section of the conservation easement] indicate that the easement's drafters intended to prohibit all commercial or industrial activities not specifically exempted." $I d$. at $* 12$. Looking at the objective and extrinsic evidence in analyzing the ambiguity, the court noted that the plaintiff sought the defendant's permission to enter into a gas lease, indicating that it suspected its conduct was not permitted under the conservation easement. $I d$. at *14.

146. No. 3388 of 2011, 2011 Pa. Dist. \& Cnty. Dec. LEXIS 367 (Pa. Com. Pl. Civ. Div. Oct. 19, 2011), aff'd, No. 1799 WDA 2011, 2013 Pa. Super. Unpub. LEXIS 3969 (Pa. Super. Ct. Feb. 21, 2013).

147. Id. at $* 1$.

148. Id. at $* 1-2$. 
property. ${ }^{149}$ In doing so, the Rays sought confirmation that this would not violate the conservation easement. ${ }^{150}$ The Conservancy informed the Rays that this activity would indeed violate the conservation easement, and the Rays subsequently brought an action for declaratory relief. ${ }^{151}$ On a motion for judgment on the pleadings, the trial court rejected the Rays' argument that the conservation easement was meant only to protect the surface of the land, and instead found that the language prohibiting the removal of oil and gas from the property to be clear and unambiguous. ${ }^{152}$ The Rays appealed, and the Superior Court of Pennsylvania affirmed, stating that the clear intention of the parties was to prohibit all removal of gas from the property, regardless of whether the gas was being removed from the surface of the conserved property or from an adjacent property. ${ }^{153}$

Ray provides a useful lesson: if a goal of a particular conservation easement is to prohibit all mineral extraction from the protected property, then the purposes of the conservation easement should be drafted so as to align with the specific restrictions. In arguing to allow gas exploration, the Rays relied heavily on what they alleged was the intent of the parties and the purpose of the conservation easement. ${ }^{154}$ Their main contention was that the intent of the parties was to protect only the surface of the land, and that any attempt to access natural gas deposits deep below the land via horizontal drilling from an adjacent property would not run afoul of this purpose. ${ }^{155}$ The drafters of the conservation easement in Ray may have prevented this litigation if they had included in the purposes section of the conservation easement a goal to protect against the depletion of subsurface resources.

While we do not have other cases exploring the interplay between fracking and land-use restrictions, we can easily see how certain land-use restrictions might be problematic. Indeed, the specific nature of enumerated restrictions generally make them a better candidate for impacting fracking than looking to the purposes or conservation value sections.

Some land-use restrictions will prevent the development of fracking under any circumstances, as is the case with the prohibition on commercial activity. More common though will be land-use restrictions that require a case-by-case inquiry. Notice, that the commercial activity case could have

\footnotetext{
149. Ray, 2013 Pa. Super. Unpub. LEXIS 3969, at*2.

150. Id.

151. Id.

152. Ray, 2011 Pa. Dist. \& Cnty. Dec. LEXIS 367, at *4-5.

153. Ray, $2013 \mathrm{~Pa}$. Super. Unpub. LEXIS 3969, at*13-15.

154. Ray, 2011 Pa. Dist. \& Cnty. Dec. LEXIS 367, at *2, 5 .

155. Id. at *5.
} 
been decided at the motion to dismiss stage because it involved only a reading of the agreement. More common would be a need for the dispute to proceed to a motion for summary judgment or to trial for a fuller development of the facts - to determine in each particular case whether fracking might violate a land-use restriction. For example, many conservation easements prohibit alteration to topography, moving of trees, and disturbance of watercourses. One cannot say that all types of fracking may necessitate the removal of trees or altering the contours of the land. The parties would have the opportunity to present evidence showing why the proposed fracking activities would or would not violate the conservation easement. The fact that this is not resolvable as a question of law, of course, would make such disputes more expensive ones (requiring the gathering of evidence and more complicated judicial proceedings).

\section{B. Step Two: Look at the State Enabling Act}

Where fracking is not prohibited (or not clearly prohibited) by the text of a conservation easement, we look to the state conservation easement statutes to determine if they pose any impediments to fracking before proceeding to other laws. We begin by examining state enabling acts to assess whether fracking appears acceptable under both the general purposes and within other restrictions and limitations. Many states have adopted some version of the Uniform Conservation Easement Act (UCEA), ${ }^{156}$ so we begin our inquiry with the UCEA and then look at a few examples of non-UCEA states. This is not an extensive investigation but illustrates the inquiry that should be done into a state's law when trying to determine how the rules might relate to fracking interests. The question we seek to answer below is whether fracking could ever be consistent with a conservation easement. Thus, we ask: considering already existing conservation easements that do not specifically address fracking or subsurface rights, is there anything in the state statutes that suggest fracking would or would not be allowed on such land? ${ }^{157}$

\footnotetext{
156. Legislative Enactment Status Conservation Easement Act, supra note 96.

157. In other work, one of the authors (working with two excellent co-authors) investigated whether state enabling acts would allow one to encumber solely subsurface rights. That is, we reviewed state conservation easement statutes to see whether the conservation purposes were consistent with environmental protection even where there were no explicit protections on the surface (no limitations on development, restrictions on land use, and protections of scenic views or ecosystems). We concluded that many state enabling acts are broad enough to enable one to protect only subsurface rights. While that represents a different inquiry, there are parallels with the questions we are asking here. Concluding that state statutes are broad enough to allow conservation of simply
} 


\section{UCEA}

The purpose of the UCEA is to sweep away the impediments of common law that made enforcement of perpetual negative easements in gross uncertain. ${ }^{158}$ The Prefatory Note to the UCEA indicates that the drafters did not believe that they were creating something new but simply clarifying the enforceability of a mechanism that in some cases already existed. ${ }^{159}$ Acceptable purposes under the UCEA "include retaining or protecting natural, scenic, or open-space values of real property, assuring its availability for agricultural, forest, recreational, or open-space use, protecting natural resources, maintaining or enhancing air or water quality, or preserving the historical, architectural, archaeological, or cultural aspects of real property." 160

Whether this language clearly prohibits fracking turns on whether one thinks fracking can be consistent with protection of natural, scenic, and open space values. While one could argue that fracking is not natural, we think a court would be hard pressed to reach that conclusion and prohibit fracking on all land encumbered by a conservation easement in a state. While courts have yet to address this question, it is unlikely a court would prohibit fracking based on the general conservation goals of the statute alone. As a mainly subsurface activity, fracking is not clearly in conflict with goals of natural and scenic protection (for example).

However, there may be cases where fracking is not possible on a certain parcel without impacting the state's conservation easement purposes. Thus, even though we are examining a state law and its relationship to fracking generally in this section, the question is one that may still need to be answered based on the individual circumstances of the parcel at issue. Notice, while this inquiry is similar to the one above where we investigate whether the conservation easement language would prohibit fracking, here we look instead at the language of the state statute. As conservation easement purposes must mirror the allowable purposes outlined in state law, it seems likely that a finding that fracking would be

the subsurface aligns with a conclusion that conservation easement statutes have a broad range of purposes and are not necessarily inconsistent with subsurface uses that have minimal impacts on the surface rights. For each investigation, we must interpret the same statutory provisions - those setting forth what the state legislature has recognized as conservation measures that meet public goals. See Jackson et al., supra note 114, at 112. See also Michael T. Fulks, Drilling and Deductions: Making the Section 170(h) Conservation Easement Work in the Shale Book Era, 116 W. VA. L. REV. 1053, 1067-70 (2014) (persuasively arguing that owners of the mineral estate should be able to obtain charitable tax credits for donating their development rights).

158. King \& Fairfax, supra note 94, at 1961.

159. See Unif. Conservation EASEMENT ACt Prefatory Note (UNIF. LAw Comm'n 1981).

160. UNIF. CONSERVATION EASEMENT ACT WITH 2007 AMENDMENTS $§ 1$ (UNIF. LAW COMM'N 2007). 
prohibited by statute in some cases would also yield a finding that the conservation easement terms themselves prohibit fracking.

Let us look for a moment more closely at the purposes language of the UCEA. Section 1 defines a conservation easement as

a nonpossessory interest of a holder in real property imposing limitations or affirmative obligations the purposes of which include retaining or protecting natural, scenic, or open-space values of real property, assuring its availability for agricultural, forest, recreational, or open-space use, protecting natural resources, maintaining or enhancing air or water quality, or preserving the historical, architectural, archaeological, or cultural aspects of real property. ${ }^{161}$

Written in another way, the UCEA gives five options for thinking about conservation easements:

1. Retaining natural, scenic OR open-space values

2. Assuring viability of the property for agricultural, forest, recreational, or open-space use

3. Protecting natural resources

4. Maintaining or enhancing air or water quality OR

5. Preserving the historical, architectural, or cultural aspects of property

This list is broad. Not only do you only need to meet one of these five, some of them have their own subcategories. One could have a UCEA conservation easement that sought only to retain existing scenic views or one that protected agricultural land, keeping it available for production. Indeed, one can even have an UCEA conservation easement that focuses solely on preserving built structures. One can envision several scenarios where subsurface activity could be consistent with fulfilling these purposes. That is to say, this language does not clearly prohibit hydrofracking.

The broad nature of the purposes is reinforced by the UCEA's Prefatory Note, which declares the Act's goal as enabling "durable restrictions and affirmative obligations to be attached to real property to protect natural and historic resources[,]" without specifically limiting the scope or nature of such protection. ${ }^{162}$ Indeed, the Act seeks to "maximize[]

161. Id.

162. Id. Prefatory Note. 
the freedom of the creators" to protect the land. ${ }^{163}$ The fact that one can impose a conservation easement solely to maintain "certain aspects of [a] house" also indicates that one could have a conservation easement that did not restrict subsurface uses. ${ }^{164}$

The comment following Section 1 of the UCEA further supports the idea that the UCEA is facilitating agreements that meet a wide variety of conservation purposes, stating:

the [conservation] easement must serve one or more of the following purposes: Protection of natural or open-space resources; protection of air or water quality; preservation of the historical aspects of property; or other similar objectives spelled out in subsection (1). ${ }^{165}$

While it is unclear why the drafters chose to repeat some of the stated purposes (and to phrase them slightly differently), what is clear is that the drafters envisioned conservation easements as being used for a broad range of conservation activities and viewed conservation easements as only needing to meet one purpose (although they may meet several conservation goals).

As with our discussion of conservation easement agreements, we again need a two-part inquiry. While the UCEA does not prohibit fracking per se, it may be that projected impacts from fracking on a certain parcel may lead to concern. Perhaps the likely impacts to a particular parcel are subsidence, water contamination, and impact to scenic vistas (due to subsidence, drilling equipment, or some other factor). Arguably a conservation easement that purported to allow such activity would be at odds with the purposes of the UCEA. Therefore, the agreement in question would not be able to resort to the protection of the UCEA for enforcement and would be constrained to the state's rules about property law, which often encumbered the use of conservation-easement-like tools.

Of course, while conservation easements must comply with state statutes and this includes having stated purposes that align with the state enabling act, courts have rarely investigated whether a conservation easement agreement actually seeks to fulfill the statutory purposes. Furthermore, no court has held that conservation easements must actually achieve either their stated goals or the statutory goals. It seems that the agreements must be made with these conservation goals in mind, but without an obligation to fulfill the goals. We could find no record of a case where the court even critically examined whether a conservation

\footnotetext{
163. Id.

164. Id.

165. Id. $\S 1 \mathrm{cmt}$.
} 
easement was impermissible for failing to adhere to the purposes section of a state enabling act. The closest we come is a case from Texas where a court considered, among other things, the State of Texas' claim that a conservation easement held by the U.S. Fish and Wildlife Service was invalid because it did not meet the state's statutory definition. ${ }^{166}$ Texas sought to invalidate the conservation easement because it sought to use encumbered land as a water reservoir instead of a wildlife refuge as planned. ${ }^{167}$ In analyzing Texas' claims, the court recognized the importance of the statutory purposes of a conservation easement, and indicated that a conservation easement could be invalidated if it did not comply with these statutory purposes. ${ }^{168}$ Discussing the state's enabling statute, the court said that "the statute is intended to provide a vehicle for the easement grantors ... and holders ... to bring an action against one another for failing to use the land in accordance with the statute and the terms of the easement." " 169 In the end, the court dismissed this portion of the Texas' claim due to lack of standing. ${ }^{170}$

Beyond the state purposes section, there might be other aspects of a conservation easement enabling act that would cause problems for landowners seeking to allow fracking or other exploitation of subsurface resources on their land. However, there does not appear to be any language in the UCEA that would form an impediment to fracking on conservation easement encumbered land in all cases.

Both the terms of the UCEA and the notes that follow it emphasize that subsurface rights will only be encumbered where the party holding such rights has signed onto the conservation easement. Section 2(d) states, "An interest in real property in existence at the time a conservation easement is created is not impaired by it unless the owner of the interest is a party to the conservation easement or consents to it."171 This provision seems to indicate that exploitation of subsurface rights is not necessarily at odds with a conservation easement.

The comment that follows UCEA Section 2 contains even stronger language:

\footnotetext{
166. City of Dallas v. Hall, Nos. 3:07-CV-0060-P, 3:07-CV-0213-P, 2007 WL 3125311, at *1 (N.D. Tex. Oct. 24, 2007), aff'd, 562 F.3d 712 (5th Cir. 2009).

167. Id. at $* 14$.

168. Id.

169. Id.

170. Id.

171. Unif. Conservation EASEMENT Act With 2007 Amendments § 2(d) (Unif. LaW COMM'N 2007).
} 
Obviously, an easement cannot impair prior rights of owners of interests in the burdened property existing when the [conservation] easement comes into being unless those owners join in the easement or consent to it. The [conservation] easement property thus would be subject to existing liens, encumbrances and other property rights (such as subsurface mineral rights) which pre-exist the easement. ${ }^{1 / 2}$

The statute by itself then cannot serve to prohibit exploitation of subsurface resources where the holder of those rights is not party to the conservation easement. It also suggests that a conservation easement might be possible even where there are other landowners whose rights are not restrained (with holder of the subsurface rights given as an example).

\section{Non-UCEA States}

\section{a. Conservation Easement Goals and Purposes}

While non-UCEA states have different lists of acceptable purposes, none of them are so narrow or stringent that they automatically prohibit fracking. The conservation easement enabling acts do not indicate that a blanket ban on fracking is likely in any state. But where fracking will disrupt the "natural conditions" of the property, we may see a conflict with the state scheme even if the conservation easement itself does not mention fracking or present a good argument for prohibiting it. Indeed, as states recognize the benefit of scenic and open space values, one can easily envision a conservation easement that protects acceptable purposes while still allowing extraction of subsurface resources.

Pennsylvania's conservation easement and preservation act has a list of purposes identical to that of the UCEA, adding only that the protection of land must occur for "public and economic benefit." "Florida is among several states that not only gives a general list of purposes, but then follows it up with a list of potential limits, stating that a conservation easement prohibits or limits any or all of the following:

(a) Construction or placing of buildings, roads, signs, billboards or other advertising, utilities, or other structures on or above the ground.

(b) Dumping or placing of soil or other substance or material as landfill or dumping or placing of trash, waste, or unsightly or offensive materials.

172. Id. $\S 2 \mathrm{cmt}$

173. 32 Pa. Stat. AnN. AND Cons. Stat. AnN. § 5053 (West Supp. 2014). 
(c) Removal or destruction of trees, shrubs, or other vegetation.

(d) Excavation, dredging, or removal of loam, peat, gravel, soil, rock, or other material substance in such manner as to affect the surface.

(e) Surface use except for purposes that permit the land or water area to remain predominantly in its natural condition.

(f) Activities detrimental to drainage, flood control, water conservation, erosion control, soil conservation, or fish and wildlife habitat preservation.

(g) Acts or uses detrimental to such retention of land or water areas.

(h) Acts or uses detrimental to the preservation of the structural integrity or physical appearance of sites or properties of historical, architectural, archaeological, or cultural significance. ${ }^{174}$

This list indicates that Florida is mainly concerned with surface implications as we see with the emphasis of "on or above the ground," in subsection (a) and the remark that the activities must "affect the surface" in subsection (d) or subsection (e)'s limitation on "surface use."175 The observation that landfill is prohibited suggests that some limitations on subsurface activity may be possible, but they are not required. In particular, the statute notes that one need not pursue all of these objectives by its statement that a conservation easement restricts "any or all" of the activities. ${ }^{176}$ Thus, as with other states, Florida offers us a list of potential, but not required, limitations. ${ }^{177}$

The goals of some states are more specific about fighting sprawl. For example, Washington's enabling act begins with a finding "that the haphazard growth and spread of urban development is encroaching upon, or eliminating, numerous open areas and spaces of varied size and character, including many devoted to agriculture, the cultivation of timber, and other productive activities, and many others having significant recreational, social, scenic, or esthetic values." ${ }^{178}$ The legislature identified such areas as "important assets to existing and impending urban and metropolitan development" and as contributions "to the welfare and

174. FLA. STAT. § 704.06(1)(a)-(h) (West 2013).

175. Id.

176. Id.

177. See, e.g., 765 Ill. Comp. Stat. AnN. 120/1. (West 2001); MD. Code AnN. Real Prop. § 2-118(b) (West 2012) (Maryland's statute will be abrogated and of no further force or effect on June 30, 2019, unless the Maryland General Assembly takes further action).

178. WASH. REV. CODE ANN. § 84.34.200 (West 2004). 
well-being of the citizens of the state as a whole." ${ }^{\prime 179}$ Washington identifies protection of such resources as being a worthy public purpose and even meriting expenditure of public funds. Differing from a delineation of acceptable purposes, this description of the goal of the state statute may assist courts grappling with whether a particular conservation easement appears in keeping with the state statutes. It does not clearly, however, answer the question of whether fracking can ever be consistent with a conservation easement in the state of Washington.

Other states focus on retaining the current or "natural" state of the land. We can see this example in Ohio. Ohio's statute offers a slightly different definition of a conservation easement:

an incorporeal right or interest in land that is held for the public purpose of retaining land, water, or wetland areas predominantly in their natural, scenic, open, or wooded condition, including, without limitation, the use of land in agriculture when consistent with and in furtherance of the purpose of retaining those areas in such a condition, or retaining their use predominantly as suitable habitat for fish, plants, or wildlife; that imposes any limitations on the use or development of the areas that are appropriate at the time of creation of the conservation easement to achieve one or more of those purposes. ${ }^{180}$

Thus, it appears in Ohio that you must be retaining land in its predominantly natural state and emphasizes "retaining" current conditions. ${ }^{181}$ It is not clear whether fracking would be prohibited under this language, but we think it is arguably stronger than what we have seen in other states. How much does an activity have to change a parcel before it is no longer in its natural state? Our reading of this language is that while it does not impose a blanket ban on hydrofracking, it could be used to argue against the practice on a particular piece of land. For example, if a geologist could demonstrate that certain areas or parcels would be at risk of increased seismic activity or groundwater contamination, allowing fracking on such conserved properties conflicts with the general goals of the state legislature in allowing conservation easements within the state.

It may be that certain fracking operations will make it impossible to meet statutory goals. For example, if you are in a state like Arizona, conservation easements are permissible as long as they either (a) preserve lands for outdoor recreation, (b) protect relatively natural habitats of wildlife and ecosystems, or (c) preserve open space for the scenic

179. Id.

180. OHIO REV. CODE ANN. § 5301.67(A) (West Supp. 2014).

181. Id. 
enjoyment of the public or pursuant to a governmental conservation policy. ${ }^{182}$ It may be hard to meet these goals (particularly (a) and (b)) on land where active fracking is occurring. Yet, this language does not automatically foreclose fracking. While most fracking scenarios will be at odds with protection of ecosystems (including the water necessary to sustain those ecosystems), it is not necessarily true. Where fracking on conserved land is fully a subsurface activity with well pads occurring on nearby lands not burdened with any public or private conservation restrictions, habitat and scenic values could still gain from the arrangement. Indeed, it may be that allowing some subsurface exploitation finances more restrictive conservation measures on other more valuable (from an ecological standpoint) parcels.

\section{b. Other Provisions Within the Enabling Acts}

Beyond the purposes sections, statutes may (but do not usually) touch on fracking-related themes. Usually this occurs where the statutes assert protection of the rights of subsurface owners. For example, in Pennsylvania, while the purposes section alone does nothing to clearly prohibit or limit fracking, later provisions of the statute address subsurface rights with regards to coal. Section 5509(d) of the Act requires notice to be given to owners of coal rights, stating:

A conservation easement affecting real property containing workable coal seams or from which an interest in coal has been severed may not be recorded or effective unless the grantor or donor of the easement signs a statement printed on the instrument creating the conservation easement stating that the easement may impair the development of such coal interest. ${ }^{183}$

This notice must be delivered to the holder of the coal interests. Presumably, the owner of the coal interest can challenge the creation of the conservation easement. This is similar to language from other states that require anyone holding another property right (including a subsurface right) to subordinate their interests to the conservation easement or to confirm that their interests will not be disrupted by the terms of the proposed conservation easement. ${ }^{184}$

182. ARIZ. REV. STAT. § 33-271(2) (2014).

183. 32 PA. Stat. AND Cons. Stat. ANN. § 5059(d) (West Supp. 2014) (emphasis added).

184. See, e.g., W. VA. CODE ANN. § 20-12-4(d) (West 2002) ("An interest in real property in existence at the time a conservation or preservation easement is created, including an unrecorded lease for the production of minerals or removal of timber, shall not be impaired unless the owner of such interest is a party to the easement or expressly consents to comply with the restriction of such 
Pennsylvania's statute also expands the list of people who have standing to bring a legal action regarding the conservation easement to include " $[t]$ he owner of a coal interest in property contiguous to the property burdened by the easement or of coal interests which have been severed from the ownership of the property burdened by the easement." ${ }^{\text {"185 }}$ This section confers standing but does not make clear what the cause of action would be. It does indicate that the legislature believed it would be possible to have conservation easements protecting the surface without an effect on subsurface mineral exploitation. Pennsylvania's Enabling Act specifically states that the statute does not affect any coal mining activities or permits in place before a conservation easement is recorded. ${ }^{186}$ That is to say, it appears that one cannot stop coal mining activity by placing a conservation easement on the property. This cuts in two directions. On the one hand, it shows political support for mining and energy exploration. On the other hand, it suggests that coal mining would regularly be inconsistent with the purposes of a conservation easement, suggesting that a similar view could be appropriate for fracking. Furthermore, the existence of a conservation easement cannot limit a holder of subsurface coal rights from access to that coal. ${ }^{187}$ The statute does not speak about subsurface rights generally, but by analogy one should not be able to limit access to subsurface oil and gas deposits without clear subordination of the mineral interest. This is akin to the process used to perfect conservation easements where mortgages burden a property. ${ }^{188}$

For land protected by a conservation easement, the parties to the conservation easement may be hampered from challenging fracking on adjacent land by Section 5055(b) of Pennsylvania's Conservation and Preservation Easement Act, which states: "No action may be brought for activities occurring outside the boundaries of a conservation or preservation easement except in circumstances where such activities have or pose a substantial threat of direct, physically identifiable harm within the boundaries of the easement."189 A few sections later, the statute

easement.").

185. 32 PA. Stat. AND Cons. StAT. ANN. § 5055(a)(7) (West Supp. 2014).

186. Id. $\S 5059$ (a) ("Nothing in this act limits, expands, modifies or preempts the rights, powers, duties and liabilities of operators or other persons under ... the Surface Mining Conservation and Reclamation Act, or . . . The Bituminous Mine Subsidence and Land Conservation Act. This act does not limit or restrict any coal mining activity which was permitted or for which an application for permit was filed prior to the recording of a conservation easement under this act.").

187. Id. $\S 5059(\mathrm{c})$.

188. See Nancy A. McLaughlin, Extinguishing and Amending Tax-Deductible Conservation Easements: Protecting the Federal Investment after Carpenter, Simmons, and Kaufman, 13 FLA. TAX REV. 217, 271 (2012).

189. 32 PA. STAT. AND CONS. STAT. ANN. § 5055(b). 
confirms that " $[t]$ he existence of a conservation easement on contiguous property may not serve as the sole grounds for designation of areas unsuitable for mining pursuant to section 4.5 of the Surface Mining Conservation and Reclamation Act." 190 While the Surface Mining Act does not cover fracking, the first section suggests that existence of conservation easements will not prevent fracking on neighboring property.

Other states may offer reasons to be cautious about fracking on land encumbered with conservation easements. For example, Nebraska and Missouri both require coordination with planning agencies in the formation of a conservation easement. ${ }^{191}$ This step may allow public entities to clarify whether they view fracking as consistent with conservation activities. Massachusetts's state law not only describes rules for conservation restrictions (their name for conservation easements) generally, but also names some specific subclasses of restrictions. One of these is the watershed preservation restriction. A watershed preservation restriction seeks to retain "land predominantly in such condition to protect the water supply or potential water supply of the commonwealth." 192 The exact contours of such restrictions may differ. Here, the state law explains that they can be used "to forbid or limit any or all (a) construction or placing of buildings; (b) excavation, dredging or removal of loam, peat, gravel, soil, rock or other mineral substance except as needed to maintain the land and (c) other acts or uses detrimental to such watershed."193 Because the statute does not require the restriction to meet all three of these requirements, it is not clear that it would prohibit fracking. However, with the demonstrated risk to water sources from fracking, a court might hold fracking to be inconsistent with the state statute.

Florida's statute suggests fracking or other subsurface resource use and extraction could be consistent with conservation easements. It specifically notes that utilities and pipelines are consistent. ${ }^{194}$ Yet, in Florida's discussion of utilities (including "pipeline transmission and distribution facilities") does not suggest as intensive subsurface use and risk to land as one might anticipate with fracking. ${ }^{195}$ New York's statute offers seemingly even greater support of fracking with explicit protection

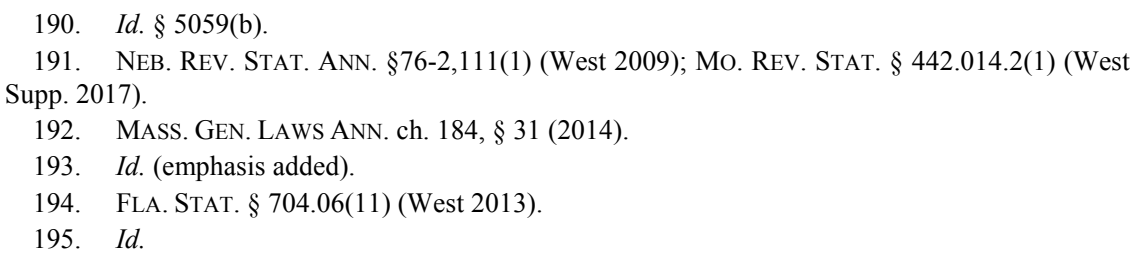


of natural gas sales and transmission. ${ }^{196}$ The statute does not explicitly refer to production of natural gas though, and with the state's current ban on fracking, this provision is likely to go untested. ${ }^{197}$

\section{Step Three: Look at the IRS Code}

Many conservation easements are donated with landowners receiving significant state and federal tax benefits. Where landowners have obtained a charitable tax deduction, they must comply with the provisions of Section 170(h) of the Internal Revenue Code. As with the state enabling acts, the Internal Revenue Code sets forth acceptable purposes:

(i) the preservation of land areas for outdoor recreation by, or the education of, the general public,

(ii) the protection of a relatively natural habitat of fish, wildlife, or plants, or similar ecosystem,

(iii) the preservation of open space (including farmland and forest land) where such preservation is-

(I) for the scenic enjoyment of the general public, or

(II) pursuant to a clearly delineated Federal, State, or local governmental conservation policy, and will yield a significant public benefit, or

(iv) the preservation of [a] historically important land area or a certified historic structure. ${ }^{198}$

None of these purposes clearly prohibits fracking, but they all have the potential to conflict with fracking activities. For example, active recreation use of land may be inconsistent with extracting natural resources from the land. The IRS regulations accompanying this section, specify that the recreation must be "for the substantial and regular use of

196. N.Y. EnVtL. CONSERV. LaW § 49-0305(3)(b) (McKinney 2008 \& Supp. 2014) (“Any conservation easement created pursuant to this title shall not limit, restrict or modify the right to construct, operate or continue the use of any facility, or impede any activity, duly authorized under the applicable provisions of the federal natural gas act (15 U.S.C. §§ 717-717 w).”).

197. See Lucia Graves, On the Faultline: New York Fracking Ban Leaves State Divided as Primary Looms, THE GUARDIAN (Apr. 16, 2016 11:23 AM), https://www.theguardian.com/ environment/2016/apr/16/fracking-new-york-primary-bernie-sanders-hillary-clinton-donald-trump (discussing New York's 2014 fracking ban).

198. I.R.C. § 170(h)(4)(A)(i)-(iv) (2012). 
the general public."199 The Vermont Supreme Court has recently found that a completely subsurface gas pipeline was consistent with the surface use of the land as a park, but not all subsurface activities may be so benign. ${ }^{200}$ Active fracking operations preclude recreation users from at least some portions of the land for safety reasons. Where fracking is causing subsidence and geological activity, the conflict with recreation use may be even greater.

A similar concern arises with protection of habitats. Whether fracking operations have the potential to conflict with habitat goals depends on the habitat at issue and how sensitive it is to different operations and land uses. The IRS regulations state that some alteration of the land does not defeat deductibility. ${ }^{201}$ The same goes for the other potential purposes: no purpose clearly prohibits fracking but all of them have the potential to conflict with fracking. Even protection for scenic purposes may prohibit fracking if there is any surface activity present, even if minimal. One of the illustrations provided by the IRS to explain the regulations gives an example where one home on ninety acres destroys the scenic value of the land. ${ }^{202} \mathrm{~A}$ follow up example suggests that where activity can be hidden from view, it will not disqualify a conservation easement. ${ }^{203}$ Where all activity is occurring below the surface, there may be no impact. However, fracking has the potential to cause subsidence and that would be a visual impact on the surface possibly defeating the deductibility of a conservation easement. Essentially, the answer to the question whether fracking will be allowed is a murky one that varies by property and level of extractive activity.

Because conservation easements are an exception to a long-held policy, it would make sense for the IRS and courts to construe the exception narrowly and take a constrained view of which conservation easements should merit a tax deduction. Alternatively, because the goal of the law is to increase land conservation, one could argue that the statute should be construed broadly to fulfill the policy goal of environmental protection. While there are several cases from tax courts and IRS private letter rulings, it is not yet clear which approach the IRS favors as the cases

\footnotetext{
199. Treas. Reg. § 1.170A-14(d)(iv)(2)(ii) (as amended in 2009).

200. In re Vt. Gas Sys., Inc., 2017 VT 83, 1 (Vt. 2017) (finding that a horizontally drilled gas pipeline would not materially interfere with surface use of the parcel as a public park). Although this case did not involve a conservation easement, similar reasoning might appear in an analysis of whether a completely subsurface use will impact surface recreational activities.

201. Id. § 1.170A-14(d)(iv)(3)(iii).

202. Id. § 1.170A-14(f) (Example 3).

203. Id. (Example 4).
} 
tend to focus on either valuation or perpetuity standards.

Courts have been more likely to review conservation easements for conformance with the purposes set out in the Internal Revenue Code than with state statutory purposes. This may be due to the fact that federal tax revenue is at stake or perhaps the IRS requirements are more stringent than a particular state statute. Most likely, however, courts review tax cases because there are IRS employees actively examining conservation easement deductions while in most states there is no similar institution confirming enforceability. ${ }^{204}$ Two cases are particularly relevant for our inquiry here. In both cases, the court upheld the IRS' denial of a tax deduction because the contributions did not conform to any of the purposes set out in the statute for a qualified conservation easement contribution.

Atkinson v. Commissioner involved a landowner who sought a deduction for conservation easements that encumbered a golf course. ${ }^{205}$ The landowner argued unsuccessfully that its conservation easements met two of the statutory purposes: (1) protection of a relatively natural habitat, and (2) the preservation of open space pursuant to a clearly delineated government policy. ${ }^{206}$ The U.S. Tax Court, relying on expert testimony, made key findings about the nature of the property and concluded that the conservation easements failed to meet either of the purposes claimed by the landowners. ${ }^{207}$ Facts critical to the court's determination were that native pine trees were not protected because the conservation easements allowed for cutting trees near the fairway; that the property was not protecting a relatively natural habitat because it was regularly sprayed with pesticides and planted with non-native grass; and that development and human traffic on the golf course prevented the property from acting as a buffer to nearby wilderness areas. ${ }^{208}$ The court also held that the

204. A few states (e.g., Maine and Virginia) do require a government agency to review the conservation easements before they are recorded. See Me. Rev. Stat. Ann. tit. 33, § 479-C (Supp. 2013) (requiring registration with Maine Department of Agriculture, Conservation and Forestry); VA. CODE ANN. § 10.1-1012 (West 2011 \& Supp. 2014) (requiring notification of the Director of the Department of Conservation and Recreation, the Virginia Outdoors Foundation). Maryland only allows land trusts to hold conservation easements where the land trust has a cooperative agreement with the Maryland Environmental Trust (a state agency) (MD. CODE ANN. REAL PROP. § 10705(a)(3)(ii) (2012)) and many of the conservation easements in the state are held or co-held by public authorities. Maryland Environmental Trust History, MD. DEP'T OF NAT. RES., http://dnr.maryland.gov/met/Pages/history.aspx (last visited Oct. 2, 2017); Maryland Environmental Trust Land Trusts, MD. DEP'T OF NAT. RES., http://dnr.maryland.gov/met/Pages/landtrusts.aspx (last visited Oct. 2, 2017).

205. 110 T.C.M. (CCH) 550, T.C. Memo. 2015-236, at *2-3 (T.C. 2015), appeal filed, Case No. 16-2083 (4th Cir. Sept. 21, 2016).

206. Id. at $* 20$

207. Id. at *20-22.

208. Id. at $* 38-42$. 
conservation easements did not meet the "open space" purpose because the landowner failed to show the connection between the conservation easements and a "clearly delineated government conservation policy" or that the general public would benefit from any scenic enjoyment. ${ }^{209}$

The IRS denied the landowners in Turner v. Commissioner a deduction for a conservation easement that limited the development of the encumbered property to thirty lots. ${ }^{210}$ The landowner developers argued that the conservation easement met the statutory purposes of preserving open space and historic preservation. ${ }^{211}$ Specifically, the developers asserted that because they could have developed up to sixty lots under local zoning laws, their voluntary limitation to thirty lots increased the amount of open space that would otherwise exist in the area. ${ }^{212}$ The U.S. Tax Court rejected this argument, concluding that there was no limit to building on the permitted thirty lots, and that, in actuality, a floodplain limited the development of the remaining acreage, making the sixty lot figure inaccurate. ${ }^{213}$ The landowner's argument regarding historic preservation was based on a nearby historic grist mill that was not actually encumbered by the conservation easement in question. ${ }^{214}$ The court concluded that the conservation easement did nothing to protect the grist mill and that there was no other historical significance to the parcel. ${ }^{215}$

Atkinson and Turner demonstrate that courts (or at least the Tax Court) are willing to invalidate a conservation easement if it strays too far from the statutory purposes set out in the Internal Revenue Code. However, these cases were both extreme examples of taxpayers attempting to abuse the system, and for that reason we think these cases would be distinguishable from most common fracking scenarios. In both of those cases, the area that was to be protected would not be left in a relatively natural state, and the properties would be heavily trafficked by people. In the case of fracking, often only a relatively small area of land for a drilling unit is physically disturbed by the process. And, in that scenario, if a conservation easement states that the disturbed area will be remediated back to its natural state, it would have an advantage over a conservation easement covering a golf course or a residential development, which are permanently in an unnatural state. These cases do not suggest that there is

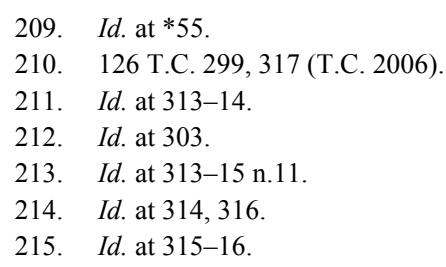


a categorical inconsistency between fracking and the statute's conservation easement purposes.

Other provisions in the Internal Revenue Code have been interpreted to allow subsurface mineral development under certain circumstances. While the Code does not specifically address subsurface activity, it does prohibit surface mining, specifically disallowing deductions "if at any time there may be extraction or removal of minerals by any surface mining method." 216 The statute contains an exception, however. Where the estate is split (surface and subsurface rights are held by different entities), and the subsurface owner is not a party to the conservation easement, the landowner seeking the tax deduction must demonstrate that "the probability of surface mining occurring on such property is so remote as to be negligible." ${ }^{217}$ Relevant factors for assessing the remoteness include "[g]eological, geophysical or economic data showing the absence of mineral reserves on the property, or the lack of commercial feasibility at the time of the contribution." 218 Note, that while this showing must be done to merit the deduction, it does not actually prohibit surface mining. As technologies change and new resources develop, it may be that resources that appear inextractible or undesirable today become profitable. To limit the possibility of surface extraction, the IRS regulations state that there will be no allowed deduction "if at any time there may be extractions or removal of minerals by any surface mining method."219 Yet, the regulations emphasize surface mining and focus on consistency with conservation purposes, explaining that "the requirement that the conservation purposes be protected in perpetuity is not satisfied if any method of mining that is inconsistent with the particular conservation purposes of a contribution is permitted at any time." 220 But if one can show that mining will have a "limited, localized impact on the real property but that are not irremediably destructive of significant conservation interests[,]" it will be allowed. ${ }^{221}$ Indeed, the IRS offers regulatory examples where subsurface gas extraction are found to be consistent with the contours of the federal law. ${ }^{222}$

The IRS statutory provisions and Treasury Regulations concerning mining on lands protected by conservation easements leave open the

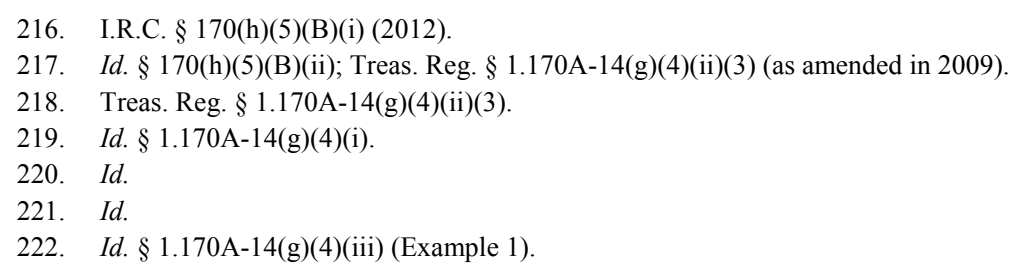


possibility of fracking. In certain cases, where the mining is not "irremediably destructive of significant conservation interests[,]" and the activity will have a limited and localized impact, deductions will still be allowed. ${ }^{223}$ The statute even states that deductions will not be denied if production facilities are concealed and the landscape is restored to its original state. ${ }^{224}$

A number of Private Letter Rulings issued by the IRS have allowed deductions where donors retained mineral interests for subsurface mining, underscoring the lenient stance the statute has towards subsurface mineral development. ${ }^{225}$ In the case of surface mining, the Internal Revenue Code distinguishes between unified and severed mineral estates. If a conservation easement donor retains a qualified mineral interest (unified mineral estate), and if at any time there may be extraction of minerals by any surface mining method, then a deduction is not allowed. ${ }^{226}$ But, in the case of severed mineral estates, there is an exception. A deduction will be allowed "if the probability of surface mining occurring on such property is so remote as to be negligible." 227 It appears that fracking can be inconsistent with the purposes set out in the Code if it is irremediably destructive of those purposes; however, we have not uncovered such a case.

The IRS has acknowledged that conservation easements may not contemplate all future development. The regulations offer some additional food for thought as they address remote future events, which fall into the same category as events that were uncontemplated by the original parties to the agreement. Specifically, the regulations note that a deduction shall not be disallowed if the interest "may be defeated by the performance of some act or the happening of some event, if on the date of the gift it appears that the possibility that such act or event will occur is so remote as to be negligible." ${ }^{228}$ The acknowledgement that the world is an uncertain place suggests that a later discovery of fracking potential on land does not defeat the deductibility of the conservation easement.

The strongest language arguing against fracking comes from the IRS regulations that require that "a donation... be exclusively for

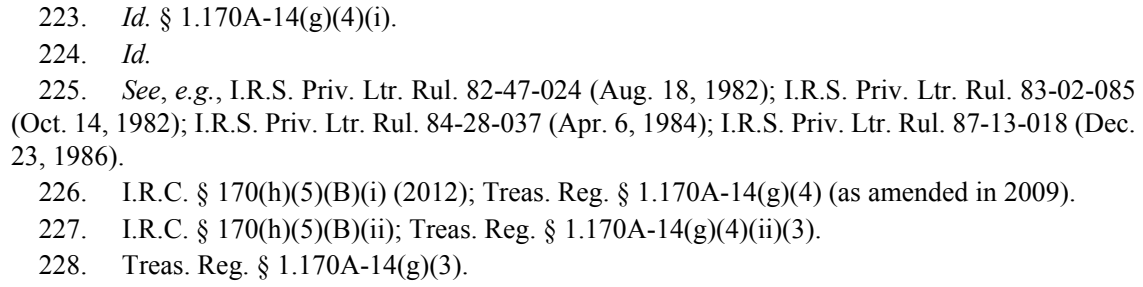


conservation purposes. $" 229$ The limitation is on the donation though, not on the land itself. The regulation does not state that the land must be used exclusively for conservation purposes but that the "donation" must be exclusively for such purposes. This language is a bit hard to parse, however, and it is not clear what the difference would be from the land's purposes and the donation's purpose. The regulations further explain "[a] deduction will not be denied under this section when incidental benefit inures to the donor merely as a result of conservation restrictions limiting the uses to which the donor's property may be put." 230

More helpful is the prohibition on inconsistent uses, which explains "a deduction will not be allowed if the contribution would accomplish one of the enumerated conservation purposes but would permit destruction of other significant conservation interests." 231 The regulations provide the example of property protected as farmland but then allowing ecosystem destruction through use of pesticides. ${ }^{232}$ This language offers the strongest indictment against fracking but not a blanket one. This language is reinforced by a later prohibition on any use of the property "in a manner that diminishes the conservation values which are intended to be protected by the contribution." ${ }^{233}$ Demonstration that allowing fracking would harm conservation benefits or values would be needed. As the impacts from fracking are studied more and more, this showing is becoming easier to make. The regulations acknowledge that some extraction of natural resources may be consistent with conservation easements (identifying timber harvesting or selective farming) but only if those uses do not "impair significant conservation interests." " only allowed where "necessary for the protection of the other conservation interests." 235 One would be hard pressed to say that fracking would ever be an activity necessary to protect other conservation interests. The only viable argument along such lines is that the money earned from fracking could be used to engage in other conservation activities, but it seems unlikely that the IRS would find such a justification acceptable.

Recall that the IRS is concerned with the deductibility of conservation

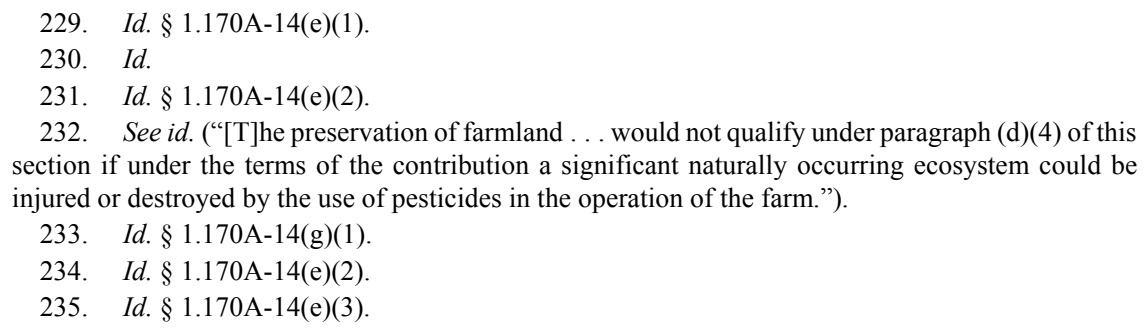


easements and not the enforceability of them. That is, violation of the statute or regulations discussed here can put tax deductions in jeopardy but tell us nothing about whether a conservation easement itself remains in place. Landowners must comply with these regulations where they want to secure federal tax benefits, but even if they fail to meet the IRS burden, the conservation easement itself might not be at risk. It will be enforced under the state enabling acts discussed above. ${ }^{236}$

\section{Step Four: Look at Funding Statutes}

Many conservation easements are established under various government programs and funded by federal, state, and local programs. For example, we may find conservation easements funded by the federal Forest Legacy Program or Wetlands Reserve Program. We would have to look to these statutes to see what they say about activities like fracking. The answer is probably nothing, but it is still good to look. This section presents two examples of statutes that fund (at least in part) conservation easements. As the holders of the purse strings, funders have a lot of power in shaping these agreements and can add more stringent restrictions than already exist under the enabling acts. However, it can be a challenge to identify which statute served as the funding for any particular conservation easement, and getting courts to enforce any rules not actually contained in the enabling act (or conservation easement text) might be a challenge. Where a conservation easement is ambiguous though, a funding statute could serve as evidence to clarify terms. Below, we offer an example of both a national and subnational funding program as samples of the type of statutes involved.

\section{Federal: Forest Legacy Program}

The Farm Bill is the federal law that has offered the most funding programs for conservation easements over the years. Many programs within that bill do or have involved conservation easements. We take one program as our example here, merely to illustrate the role that funding programs can play in shaping and enforcing conservation easements. In 1990, Congress established the Forest Legacy Program with the hopes of slowing the conversion of forestlands to nonforest uses. ${ }^{237}$ A voluntary incentive-based program, the Forest Legacy Program endorses the use of

236. See supra Section III.A.

237. Food, Agriculture, Conservation, and Trade Act of 1990, Pub. L. No. 101-624, § 1217, 104 Stat. 3359, 3528 (codified as amended at 16 U.S.C. $\$ 2103$ c (2012)). 
conservation easements for forest conservation. ${ }^{238}$ The role of conservation easements in the program is slightly complicated, but for our purposes here we only need to understand that the program identifies areas in need of protection (Forest Legacy Areas) and then helps fund acquisition of full title and/or conservation easements on land within those areas. ${ }^{239}$ Federal law outlines some requirements for the conservation easements involved and federal guidance in the form of the Forest Service's Forest Legacy Program Handbook gives examples and details for conservation easements in the program. Neither the law nor the guidance speak to subsurface resource extraction or fracking.

Conservation easement purposes in this program include "protection of important scenic, cultural, fish, wildlife, and recreational resources, riparian areas, and other ecological values." ${ }^{240}$ As with the state enabling acts discussed above, these purposes are broad enough that some subsurface exploitation of natural resources may still be consistent with meeting these goals. Examination, as before, would need to be on a caseby-case basis. The most important characteristic of conservation easements in the Forest Legacy Program is that they seek to prevent the conversion of forests to nonforest uses. ${ }^{241}$ All conservation easements in this program must be held by government agencies. ${ }^{242}$ And all land in the program must operate in accordance with a forest management plan. ${ }^{243}$

The Forest Service has not promulgated regulations for the Forest Legacy Program, but instead has used guidance in the form of two documents: the FLP Handbook and the FLP Guidelines. The Handbook contains a nonexclusive checklist of potential conservation easement

238. 16 U.S.C. § 2103c. See also Jessica Owley \& Stephen J. Tulowiecki, Who Should Protect the Forest?: Conservation Easements in the Forest Legacy Program, 33 PUB. LAND \& RESOURCES L. REV. 47, 59-64 (2012).

239. 16 U.S.C. $\$ 2103$ c; USDA Forest Service, Forest Legacy Program Users' Guide $17-$ 18 (2006) [hereinafter FLP Handbook], https://www.fs.fed.us/spf/coop/library/flp_usersguide.pdf. The Forest Service provides up to $75 \%$ of the funding, requiring a $25 \%$ cost share from other sources. $I d$. at 43 . This cost share might be state, local, or private funds. Id. It might also be a donation of $25 \%$ of the value of the conservation easement or land involved. See id. For example, envision a forested parcel with a conservation easement valued at $\$ 100,000$. The landowner accepted a bargain sale price of $\$ 75,000$ and then claimed a tax deduction for $\$ 25,000$. We now have a conservation easement that should comply with the state enabling act, Internal Revenue Code, and the Forest Legacy Program requirements. There is an argument that conservation easements created under a federal program need not comply with state enabling acts, but we will put that aside for now as most federal programs explicitly seek compliance with state property law. See Owley, Enforceability, supra note 84, at 292-98; Owley, Exacted Conservation, supra note 78, at 53-54.

240. 16 U.S.C. $\S 2103 \mathrm{c}(\mathrm{a})$.

241. Id. $\S 2103 \mathrm{c}(\mathrm{e})$.

242. Owley \& Tulowiecki, supra note 8 , at 62.

243. USDA Forest SERVICE, FinAL ForeSt LEGACY PROGRAM IMPLEMENTATION GUIDELINES 21 (2003), https://www.fs.fed.us/spf/coop/library/fpl_guidelines.pdf. 
rights and restrictions. ${ }^{244}$ Nothing on the list refers to fracking or any other subsurface uses of the land, yet the model conservation easement checklist includes "mineral development" and "topography modification" as prohibited uses. ${ }^{245}$ The Program (again, through agency guidance but not by statute) does require certain language to appear in conservation easements, but the language does not include anything about mineral rights. ${ }^{246}$ Two of the three sample conservation easements in the Handbook prohibit "mining, drilling, or mineral development" but allow designated areas for extraction of sand, gravel, and stone for use on site. ${ }^{247}$ This prohibition is followed with specific rules about prospecting minerals and removal of subsurface resources including oil, gas, and geothermal energy. ${ }^{248}$ These rules (and again this is sample language, not required language) require prior written notice to the United States and limit the land used to "[o]nly so much... as is necessary" with removal of equipment within a year of termination of the operation and restoration of the land. ${ }^{249}$ The other sample conservation easement prohibits all mineral use, excavation, and dredging. ${ }^{250}$ While the conservation easement does not appear to contemplate wholly subsurface uses, the prohibition could be read to encompass gas and oil extraction of any kind.

The sample conservation easements indicate that fracking could be consistent with the Forest Legacy Program, but it would also be consistent to prohibit the activity. Simply having received funds for a conservation easement from the program does not automatically mean that the land is unavailable for development of subsurface resources. Because of the Forest Service's priority system for use of funds, it seems unlikely that a Forest Legacy Program conservation easement would burden land with fracking potential. Yet, as techniques develop, it may be that land that seems unavailable or unattractive for fracking today will be so in the future. This statute serves not as an example of a federal program that prohibits fracking but as an example of the type of inquiry one should do when determining whether fracking will be permissible. As parties (or

\footnotetext{
244. FLP Handbook, supra note 239, at 77.

245. Id. at 78 .

246. See id. at 81. Conservation easements must contain: (1) a statement regarding cost share, (2) an explicit reference to the IRS Code on conservation easements, (3) a general statement of Forest Legacy Program purposes and acknowledgment that the conservation easement is consistent with those proposes, (4) a clause regarding reversion of funds to Forest Service in case of termination, (5) affirmation that the conservation easement is perpetual, and (6) confirmation that the conservation easement is held by a qualified government entity. See id.

247. Id. at 85 .

248. Id. at 86 .

249. Id. at $86,104$.

250. Id. at 96 .
} 
courts) assess whether fracking can be consistent with encumbered land, looking to the funding statute can provide both specific and general guidance regarding the purposes of the land restriction.

\section{Local: Town of Clarence Greenprint}

Many local programs (often established by referenda) fund conservation easement acquisition. An example program comes out of the township of Clarence in Western New York. A historically agricultural community, Clarence faces intense development pressures as a suburb of Buffalo, New York. A 2002 public referendum created the Greenprint program by a $2 / 3$ vote of town residents. ${ }^{251}$ This created the ten-year Greenprint Preservation Program with $\$ 12.5$ million in bond funding. ${ }^{252}$ In the first ten years, the program preserved over 1,000 acres at a cost of $\$ 6.8$ million and the Town Board authorized a ten-year extension, which was later approved by public referendum. ${ }^{253}$

No local law specifies what restrictions are included in these conservation easements or dictates the terms. Instead, a town committee works with the local land trust to analyze each proposed property and determine whether it fits within the goals of the program. When a property is deemed desirable, public funds are used for either an outright purchase or encumbrance with a conservation easement. While we could find no restriction on fracking within the Greenprint program itself, many of the members of the committee and land trust are against fracking and would likely view it as an inconsistent land use. Indeed, the land trust typically contains the following provision in its conservation easements: "Mining, extraction of soil, sand, gravel, rock, hydrocarbons, or any mineral substance, using a surface mining method or any other extractive

251. Town of Clarence Farmland Prot. Comm. With Assistance from Am. Farmland TR., Appendix I: Greenprint Program PowerPoint Presentation 3, in Town OF Clarence Agricultural AND FARMLAND PROTECTION PLAN (2012), https://docs.google.com/ gview?url=http $\% 3 \mathrm{~A} \% 2 \mathrm{~F} \% 2 \mathrm{Fuploads}$.oneregionforward.org\%2Fcontent $\% 2 \mathrm{Fuploads} \% 2 \mathrm{~F} 2012 \% 2 \mathrm{~F} 1$ $2 \% 2$ FClarence-Agricultural-and-Farmland-Protection-Plan-Final.pdf; Town of Clarence, N.Y., Board Meeting Minutes (Aug. 28, 2002) (on file with author) (describing adoption of bond resolution to finance land appropriation by $2 / 3$ vote).

252. Joe Kirchmyer, Innovative Clarence Greenprint Wins a 2014 NY Upstate American Planning Association Award, WGRZ Clarence (Sept. 23, 2014, 3:54 PM), http://clarence.wgrz.com/news/environment/194321-innovative-clarence-greenprint-wins-2014-nyupstate-american-planning-association-award.

253. Town of Clarence, N.Y., State of the Town Address (Jan. 22, 2014), http://www2.erie.gov/clarence/sites/www2.erie.gov.clarence/files/uploads/State\%20of\%20the\%20T own $\% 20$ Planning\%20\%20Zoning.pdf; Town of Clarence, N.Y., Board Meeting Minutes (June 27, 2012) (on file with author). 
technique, is prohibited." 254 As the Greenprint program is incorporated into the local planning law for Clarence, it also serves as a reminder to confirm that fracking is consistent with local land use laws that often limit extractive activities to certain zones or areas.

\section{E. Step Five: Look at Exacting Law}

Increasingly, conservation easements are established under permitting programs. For example, we often see conservation easements as permit conditions under the Clean Water Act protecting wetlands or under the Endangered Species Act protecting habitats. They are used extensively in the land-use planning context with towns requiring developers to protect open space with conservation easements. For such agreements, it may also be necessary to examine what those underlying laws and associated permits require. As with the funding programs above, a challenge here may be identifying under which laws the conservation easement is exacted. Whether conservation easements identify the statute or program that they are associated with is inconsistent. Below, we give brief introductions to two laws (again national and subnational) to help create the roadmap of how one might assess whether fracking is consistent with a current conservation easement.

\section{Federal: Endangered Species Act}

The U.S. Endangered Species Act seeks to protect biodiversity by limiting the destruction of threatened and endangered species. ${ }^{255}$ One of the ways it does so is by protecting the habitat of such species. Section 9 of the Act prohibits the taking of protected species, including adverse habitat modification that causes physical harm to an individual species. ${ }^{256}$ To alleviate the onerous nature of the Section 9 restrictions, which apply to everyone under the jurisdiction of the United States and includes actions on private lands, Congress modified Section 10 to the Act in $1982 .{ }^{257}$

254. E-mail from Kathleen McCormick, Stewardship Dir. of the W. N.Y. Land Conservancy, to Jessica Owley, Professor of Law, SUNY Buffalo Law School (Apr. 12, 2017, 11:15 AM) (on file with author).

255. 16 U.S.C. §1531(b) (2012); see also Robert L. Fischman, Endangered Species Conservation: What Should We Expect of Federal Agencies?, 13 PUB. LAND L. REV. 1, 1 (1992).

256. 16 U.S.C § 1538(a)(1)(B) (2012); see Michael C. Blumm \& George Kimbrell, Flies, Spiders, Toads, Wolves, and the Constitutionality of the Endangered Species Act's Take Provision, 34 ENVTL. L. 309, 326 (2004). See also Babbitt v. Sweet Home Chapter of Cmtys. for a Great Or., 515 U.S. 687, 690 (1995).

257. Endangered Species Act Amendments of 1982, Pub. L. No. 97-304, § 6, 96 Stat. 1411, 1422 (1982); see also Federico Cheever, An Introduction to the Prohibition Against Takings in Section 9 of 
Section 10 creates a permit program, allowing incidental take of a species where done in compliance with a federal permit. ${ }^{258}$ The federal permitting program requires mitigation for any likely negative impacts on species, and this mitigation commonly takes the form of protecting habitats with conservation easements. ${ }^{259}$

The Endangered Species Act does not provide any rules for the conservation easements exacted under it. Nor are the regulations helpful on that front. Instead, agency guidance in the form of the Habitat Conservation Planning and Incidental Take Permit Processing Handbook (commonly called the HCP Handbook) is the best tool for understanding the contours of the statute and how it works - even if it is not legally binding. The U.S. Fish and Wildlife Service together with the National Oceanic and Atmospheric Administration (NOAA) Fisheries (the agencies charged with implementation of the Endangered Species Act) issued a revised Handbook in December 2016. ${ }^{260}$

The Handbook acknowledges the key role conservation easements play in effectuating the goals of the Endangered Species Act and gives examples of previous permits and conservation plans that involved conservation easements. ${ }^{261}$ In a departure (and marked improvement) from the previous handbook, the 2016 HCP Handbook details components that should be included in any conservation easement exacted under the Act. ${ }^{262}$ The agency requires adherence to state property law, review by legal counsel, rights to enforcement, and prohibitions on actions "that would be incompatible with the mitigation property's primary function as a habitat for species."263 While the Handbook does not directly refer to fracking, it does address the issue of mineral rights, taking an approach similar to that of the IRS, stating:

the Endangered Species Act of 1973: Learning to Live with a Powerful Species Preservation Law, 62 U. Colo. L. Rev. 109, 150, 176 (1991); Craig Anthony (Tony) Arnold, Conserving Habitats and Building Habitats: The Emerging Impact of the Endangered Species Act on Land Use Development, 10 STAN. ENVTL. L.J. 1, 30-36 (1991).

258. 16 U.S.C. $§ 1539$ (a) (2012).

259. Jessica Owley Lippmann, Exacted Conservation Easements: The Hard Case of Endangered Species Protection, 19 J. ENVTL. L. \& LiTiG. 293, 320-21 (2004).

260. Habitat Conservation Planning and Incidental Take Permit Processing Handbook, U.S. FISH \& WILDLIFE SERVICE AND NOAA FISHERIES, https://www.fws.gov/endangered/what-wedo/hcp_handbook-chapters.html (last updated Dec. 21, 2016).

261. Id. at 9-9-9-13.

262. Id. at 9-16. While the Handbook does not contain sample conservation easements, it refers to "[s]tate-specific" conservation easement templates. Id. We have not yet determined what this might refer to or if the intention is simply a reference to state enabling acts.

263. Id. 
If sub-surface mineral rights are severed, it is preferable that the surface property owner negotiates a purchase of the mineral rights, or surface access to the minerals. If purchase of the mineral rights are not feasible, and the mineral rights owner has access to the surface, obtain a minerals assessment report ("remoteness letter") to determine the likelihood of minerals development before determining whether an easement on the property would be acceptable for mitigation. ${ }^{264}$

The Endangered Species Act statute, regulations, and agency guidance nowhere prohibit fracking on conservation easements exacted under the Act. However, the requirement that the conservation easements must work first and foremost to protect habitat indicates that in some scenarios fracking will be an inconsistent use. Now, once again, the question to ask becomes a more detailed one based on the same case-by-case reasoning. Will fracking on this conservation easement impair the species (or its habitat) that this particular section 10 permit is working to protect?

\section{State: California Coastal Act}

State laws also result in the exaction of conservation easements. One such example is the California Coastal Act. ${ }^{265}$ A 1972 statewide voter initiative (Proposition 20) created the California Coastal Commission to protect public interests (largely related to access) along the Pacific Coast. $^{266}$ In 1976, the California legislature expanded the scope of the Commission to protect coastal resources generally including improving access, recreation, and environmental protection. ${ }^{267}$ While charging the Coastal Commission with protecting the state's coastal areas, the Coastal Act also imbued the agency with land-use regulatory powers. ${ }^{268}$ Among its duties and powers, the Commission implements a permitting system that seeks to minimize visual and ecological impacts along California's coast. ${ }^{269}$ When it issues a permit, the Commission requires the mitigation of any negative impacts to public interests in the Coast. ${ }^{270}$

\footnotetext{
264. Id.

265. CAL. PUB. Res. CODE $\S 30000$ (West 2007).

266. Todd T. Cardiff, Comment, Conflict in the California Coastal Act: Sand and Seawalls, 38 CAL. W. L. REV. 255, 262 (2001) (describing the history of the California law).

267. Id.

268. See Cal. Pub. Res. Code $\S 30001.5$ (West 2007).

269. CAL. Pub. Res. CODE $\$ 30600$ (West 2007); Meg Caldwell \& Craig Holt Segall, No Day at the Beach: Sea Level Rise, Ecosystem Loss, and Public Access Along the California Coast, 34 ECOLOGY L.Q. 533, 548 (2007).

270. Nollan v. Cal. Coastal Comm'n, 483 U.S. 825, 837 (1987), is a famous case where the Supreme Court held that the exacted mitigation must have a substantial nexus with the impact caused. Thus, the impacts on view should be mitigated by providing viewing points. See id. Impacts on access
} 
Conservation easements are commonly exacted under this statute to protect coastal lands and prohibit development of such areas in perpetuity. Where a conservation easement has been exacted, one should look to the statute to determine whether it contains any impediments to fracking. The overarching goal of the California Coastal Act is to protect the "natural and scenic resources" of the "California coastal zone." 271 Specifically, the Act seeks "to promote the public safety, health, and welfare, and to protect public and private property, wildlife, marine fisheries, and other ocean resources, and the natural environment" by "protect[ing] the ecological balance of the coastal zone and prevent[ing] its deterioration and destruction." 272

Conservation easements implementing this statute thus need to adhere to those goals. If the statute stopped there, we would have the same lesson as we learned from the Endangered Species Act above, and we would make a case-by-case inquiry into each conservation easement to see whether fracking would disrupt goals of coastal protection. However, the California Coastal Act has even stronger language suggesting that fracking would rarely be consistent. Because coasts are sensitive ecological areas and the hydrology and geology of the coast makes containment of environmental hazards complicated, the Act requires the Commission to establish special rules protecting the coastal areas "against the spillage of crude oil, gas, petroleum products, or hazardous substances."273 Clearly concerned about oil spills (likely with the 1969 Santa Barbara spill relatively fresh in their minds), ${ }^{274}$ the legislature chose strong language that goes beyond oil spills to also protect against gas spills. With the potential release of both gas and contaminated fracking fluid associated with hyrdrofracking activities, it seems unlikely that a court would find fracking on exacted conservation easements consistent with the California Coastal Act. ${ }^{275}$

\footnotetext{
would require more access points, etc. See generally Peter F. Neronha, Note, A Constitutional Standard of Review for Permit Conditions, Exactions, and Linkage Programs: Nollan v. California Coastal Commission, 30 B.C. L. REV. 903 (1989) (analyzing the Nollan decision and its impact on permit conditions and linkage programs).

271. CAL. Pub. Res. CODE $\S 30001$ (a)-(b) (West 2007).

272. Id. §30001(c).

273. CAL. PUB. Res. CODE $\S 30232$ (West 2007).

274. Christine Mai-Duc, The 1969 Santa Barbara Oil Spill That Changed Oil and Gas Exploration Forever, L.A. TIMES (May 20, 2015, 6:38 PM), http://www.latimes.com/local/lanow/lame-ln-santa-barbara-oil-spill-1969-20150520-htmlstory.html.

275. The Coastal Act does acknowledge that there could be narrow circumstances where mineral extraction is allowed. CAL. PUB. RES. CODE $\S \S 30233(a)(5), 30705(a)(5)$ (West 2007). Sections 30233 and 30705 suggest mineral extraction in only narrow circumstances. Id. (providing the example given of extracting sand for beach restoration).
} 


\section{F. Step Six: Consider Laws Governing Charitable Organizations}

Where conservation easements are held by land trusts (as is often the case), we may also need to examine the laws governing charitable organizations. Each state defines who is an eligible holder of conservation easements, as does the Internal Revenue Code. ${ }^{276}$ While the exact contours vary, most land trusts are tax exempt (under I.R.C. §501(c)(3)) nongovernmental organizations with land conservation as one of their main objectives. As charitable organizations, they must comply with federal laws governing such organizations or risk losing their tax-exempt status. Additionally, as chartered charitable organizations, they must comply with state laws that generally put such organizations under the authority of the state attorney general. ${ }^{277}$

To maintain tax-exempt status, land trusts may not engage in any action that "inures to the benefit" of any individual. ${ }^{278}$ In terms of fracking, this puts an obligation on land trusts to ensure that both the original conservation easement and any permitted amendments or allowances under the conservation easement are not done with the goal of providing private benefit. Land trusts must also comply with the state laws governing charitable organizations, which means adherence to a charter that seeks to promote public good or risk revocation of that charter. Land trusts must comply with their charter and allowing fracking may conflict. $^{279}$

\section{PROPOSALS AND CONCLUSION}

These steps represent the journey one would take in seeking to assess whether fracking operations could be conducted on land currently encumbered with a conservation easement. We easily conclude "it depends," and that the analysis requires case-by-case consideration. No state enabling act prohibits fracking. While there might be something within the funding or exacting statutes, it seems unlikely to be a blanket

276. See, e.g., UNIF. CONSERVATION EASEMENT ACt With 2007 AMENDMENTS § 1(2) (UNIF. LAW Comm'N 2007); CAL. Civ. Code § 815.3(a) (West 2007); Colo. Rev. STAT. ANN. § 38-30.5104(2) (West 2007); I.R.C. § 170(h)(3) (2012).

277. Cheever, Public Good, supra note 80, at 1083-84.

278. Id. at 1085 .

279. Connected to this need to review the laws regarding the holders of conservation easements, in some states (and in some circumstances) conservation easements are viewed as charitable trusts and the guidelines for charitable trusts might limit changes to conservation easements and might guide interpretation of their terms to focus on the intent of the original parties. See Nancy A. McLaughlin \& W. William Weeks, Hicks v. Dowd, Conservation Easements, and the Charitable Trust Doctrine: Setting the Record Straight, 10 WyO. L. REV. 73, 76 (2010). 
prohibition. Indeed, it becomes a question we cannot answer without a site assessment involving scientific experts and a legal analysis of the laws and agreements in place.

We conducted our analysis here assuming someone wanted to be able to engage in fracking activities and wanted to assess whether it is permitted. The inquiry would take the same form if conducted by a conservation easement holder facing a landowner request. There is another possible group though who might be interested in conducting such an analysis. What if community members or activists oppose fracking, but the landowner and conservation easement holder agree that it fits within the contours of allowable activity? While someone trying to assess the legality of fracking would engage in the same analysis as the landowner or conservation easement holder (perhaps reaching different conclusions), the community member would have an additional obstacle of needing to show standing. For the most part, conservation easement related cases are brought by the holder, the landowner, or a governmental entity with some level of involvement (e.g., third-party enforcement rights, exacting entity, state attorneys general, specific agencies identified by state statute). This means that someone opposing fracking on conservation lands that is not a party to the conservation easement will have to add a step to their analysis of assessing the rules for standing in their jurisdiction. Generally, however, courts have not been that receptive to such plaintiffs. ${ }^{280}$

Reflecting upon this complicated inquiry, we see that what appears to be a simple question (can I conduct hydrofracking activities on land encumbered by a conservation easement) is not simple. Indeed, what we conclude is that it can be an expensive question to answer. ${ }^{281}$ Much of this complication could be avoided by including specific consideration of fracking within the terms of conservation easements in the future. While easy to say, however, it is impossible to include provisions addressing all potential future uses. Here then fracking is simply one example of a land use that might emerge. We can add to that list things like cell phone

280. For example, in City of Dallas v. Hall, the federal district court held that neither the City of Dallas nor the Texas Water Control Board had standing to challenge the validity of a conservation easement. Nos. 3:07-CV-0060-P, 3:07-CV-0213-P, 2007 WL 3125311, at*14 (N.D. Tex. Oct. 24, 2007), aff' $d, 562$ F.3d 712 (5th Cir. 2009). The court reasoned that "the [Texas Conservation Easement Statute] is intended to provide a vehicle for the easement grantors ... and holders ... to bring an action against one another for failing to use the land in accordance with the statute and the terms of the easement." Id. at * 14 .

281. As Korngold points out, it is best to be as specific as possible in your conservation easements so you do not need to go past the motion to dismiss stage. Korngold, Conservation Easements, supra note 3 , at 140 . If a conservation easement is ambiguous, a court may want to conduct discovery and move to the summary judgment stage. Id. That can be pricey. 
towers, marijuana cultivation, and wind turbines. ${ }^{282}$ We must acknowledge that some land uses will emerge that were not contemplated by the parties to the agreement. We recommend that those entering into conservation easements consider specifically what will be the procedure and criteria for considering whether new land uses or activities will be consistent with the goals of the original parties and the intent of the conservation easement. Where there is added public involvement (public funding or exaction schemes) arguably the need to protect the public investment should be the highest goal.

Indeed, if you can actually conduct fracking on lands encumbered with conservation easements, it makes one reconsider the appraisals and tax breaks. If fracking is allowed (and lucrative), perhaps the landowner has just received bigger tax breaks than she should have. It may not have been something contemplated in the appraisal process for the conservation easement and it may be that tax deductions associated with conservation easements already questioned by some will become more suspect. ${ }^{283}$

This question need not be answered by the conservation easement agreement itself though. There is opportunity for policymakers and funders to play a role. A state legislature could choose to amend their conservation easement statute to include a rule that fracking is inconsistent with the tool. For example, Governor Cuomo in New York has placed a moratorium on fracking. ${ }^{284}$ If the state legislature wanted to reinforce support of the ban, it could amend the state conservation easement statute. ${ }^{285}$ The same could be done for funding statutes or programs. If Clarence, New York wants to make sure fracking is prevented on the land it just paid a lot to protect, it might consider adding such a requirement. Or, for exaction programs, if the California Coastal Commission is concerned about potential impacts on water from fracking, it could issue

282. See Jessica Owley, Unforeseen Land Uses: The Effect of Marijuana Legalization on Land Conservation Programs, 51 U.C. DAVIS L. REV. (forthcoming 2018) (manuscript at 22-23), https://papers.ssrn.com/sol3/papers.cfm?abstract_id=3025416.

283. If a court looks to extrinsic evidence to interpret a conservation easement, appraisal value might be helpful. Does the appraisal price suggest that mineral rights would be locked up or exploitable?

284. Thomas Kaplan, Citing Health Risks, Cuomo Bans Fracking in New York State, N.Y. TIMES (Dec. 17, 2014), https://www.nytimes.com/2014/12/18/nyregion/cuomo-to-ban-fracking-in-newyork-state-citing-health-risks.html.

285. A tricky question is whether such a statute would only affect future conservation easements or could reach into already existing agreements as well. The question is whether the landowner had the right to exploit subsurface minerals by fracking and whether the statute unconstitutionally denies them that right without the payment of just compensation. One might be able to demonstrate that where the state has banned fracking, the fair market value of the right to frack is worth zero so a takings analysis would not get you very far. A conservation easement though as a perpetual agreement can have more staying power than a governor's environmental protection policy. 
regulations that clearly prohibit fracking on any conservation easement lands they hold or that are exacted in its permit process.

We believe that it is best for state conservation easement statutes to clearly express the jurisdiction's view of fracking on conserved land. Such a statement embodies the general will of the people of the state in establishing conservation programs where individuals can be the beneficiaries of significant government largesse. The public should think carefully and be clear about what it is surrendering. For this same reason, it would be good for the IRS to clarify in regulations or a letter ruling (or for Congress to clarify by statute) whether federal tax benefits should be available with regard to lands where fracking may or will occur. Alongside these public policy measures, individuals who enter into conservation easements may want to use that mechanism to clearly express their desires with respect to the activity. Parties have the ability to trump state and local laws regarding fracking where they seek to make more limited restrictions on land use. Even in areas where laws allow fracking, land trusts can prohibit it on lands that they protect. In such cases, fracking restrictions should appear clearly in the text of the conservation easements. 